\title{
Hematopoietic Stem Cell Molecular Targets and Factors Essential for Hematopoiesis
}

\section{Pawan Kumar Raghav and Gurudutta Gangenahalli*}

Division of Stem Cell and Gene Therapy Research, Institute of Nuclear Medicine and Allied Sciences (INMAS), Delhi, India

\begin{abstract}
Hematopoietic Stem Cells (HSCs) gained popularity in the area of medicine because of its remarkable potential to cure an enormous range of human diseases. These stem cells are used for therapeutic purposes for its regenerative capacity and possessed hematopoiesis. This process reflects characteristic properties, proliferation, and differentiation. These behaviors are a result of protein-mediated molecular interactions. However, these molecular interactions underlying are yet to be explored. Thus, the present review focuses on the molecular basis of hematopoiesis wherein, significant molecular interactions which regulate differentiation and proliferation has been discussed. Primarily, we have addressed the role of cytokines, transcription factors, proliferation, and pathways involved in hematopoiesis. Also, relationship with multiple cytokines, small molecules, nutrients, cell-cell contacts and the extracellular matrix which impel a cascade of signals that controls stem cell behavior and fate has been summarized in this review. A large number of datasets of hematopoiesis is publicly available to researchers around the world. This review also provides databases on hematopoiesis which will be very beneficial in facilitating common analysis, basic research and clinical diagnosis for the treatment of blood-related disorders.
\end{abstract}

Keywords: Stem cells; Proliferation; Differentiation; Hematopoiesis; Cytokines; Transcription factors

\begin{abstract}
Abbreviations: HSCs: Hematopoietic Stem Cells; JAK: Janus Kinase; JM: Juxtamembrane; MAPK: Mitogen-Activated Protein Kinase; PI3K: Phosphoinositide 3-Kinase; PKC: Protein Kinase C; PLC- $\gamma$ : Phospholipase C- $\gamma$; PTK: Protein Tyrosine Kinase; SCF: Stem Cell Factor; SH2: Src Homology 2; STAT: Signal Transducers and Activators of Transcription; HSCs: Hematopoietic Stem Cells; SHP-1: Src Homology 2 Domain Containing Phosphatase-1; SHP-2: Src Homology 2 Domain Containing Phosphatase-2; PTPs: Protein Tyrosine Phosphatases; ESCs: Embryonic Stem Cells; ASCs: Adult Stem Cells; PU.1: Purine rich box1; LT-HSCs: Long-Term reconstituting Hematopoietic Stem Cells; ST-HSCs: Short-Term repopulating Hematopoietic Stem Cells; CLP: Common Lymphoid Progenitor; CMP: Common Myeloid Progenitor; BMT: Bone Marrow Transplantation; MEP: Megakaryocytic Erythroid Progenitors; GMP: Granulcocyte Monocyte Progenitor; GATA-1: Erythroid Transcription factor of the GATA family; C/EBP: CCAAT/Enhancer Binding Proteins; FOG1: Friend of GATA-1; EGRS: Early Growth Response Protein-1; WBCs: White Blood Cells; RBCs: Red Blood Cells; AML1: Acute Myeloid Leukemia 1; NK: Natural Killer; MLL: Mixed Lineage Leukemia; SCL/ TEL: T cell acute leukemia; bHLH: Basic Helix Loop Helix; ETS: E26 Transformation-Specific or E-Twenty-Six
\end{abstract}

\section{Introduction}

Based on origin, stem cells are broadly classified into Embryonic Stem cells (ESCs); Umbilical Cord Blood Stem Cells (UCBSCs); and Adult Stem cells (ASCs) [1,2]. ASCs have been identified in umbilical cord blood and the placenta which can lead to various types of blood cells. Bone marrow cells are the secondary source of ASCs, which consist of HSCs and Mesenchymal Stem Cells (MSCs) [3].

HSCs contain the potential of self-renewal and differentiation into specialized blood cells. HSCs reside in a niche within the bone marrow and are mainly present in the G0 phase of the cell cycle [4,5]. These quiescent cells are atypical cells and obtained from one in 10,000 bone marrow cells [6]. These cells are present in an endosteal and vascular niche composed of crosstalk network between HSCs, osteoblasts, endothelial and perivascular reticular cell. The receptors present on these cells interact with cytokines, chemokines, integrins, and morphogens which lead to committed progenitor cells [7]. HSCs produce Colony Forming Unit-Granulocytes, Erythrocytes, Megakaryocytes, and Macrophages (CFU-GEMM) [8]. The cytokine, Granulocyte Macrophage-Colony Stimulating Factors (GM-CSF) or Granulocyte-Colony Stimulating Factors (G-CSF) triggers the differentiation of human myeloid cells [9].

Stem cell proliferation is maintained by factors c-Kit ligand, Stem Cell Factor (SCF), Thrombopoietin (TPO) and morphogens (Notch ligands, Wnt, Hedgehog, TGF $\beta$, and BMP), etc., [10-12]. These factors provide signals that control their fate decision through differentiation into multiple lineages regulating their self-renewal. The SCF mediated proliferation in stem cells is regulated by their interaction with its receptor, c-Kit. This interaction activates the intracellular signaling which is negatively regulated by SHP-1/SHP-2 (Src (v-src avian sarcoma [Schmidt-Ruppin A-2] viral oncogene homolog) homology 2 (SH2) domain-containing phosphatase-1/2) [13]. Transcription factors, PU.1, c-Jun, GATA-1, and CCAAT/Enhancer Binding Proteins a (C/EBPa) regulates the myeloid differentiation [4]. The critical role of molecules which control these properties is an important aspect that must be considered while identifying potential target for designing a drug. Therefore, for successful application of HSCs for therapeutic purposes, it is essential to determine the targets and factors to understand the mechanisms that govern its fate.

*Corresponding author: Gurudutta Gangenahalli, Division of Stem Cell and Gene Therapy Research, Institute of Nuclear Medicine and Allied Sciences (INMAS), Delhi, India, Tel: 91-011-23905144; Fax: 91-011-23919509; E-mail: gugdutta@rediffmail.com

Received October 31, 2018; Accepted November 12, 2018; Published November 26, 2018

Citation: Raghav PK, Gangenahalli G (2018) Hematopoietic Stem Cell Molecular Targets and Factors Essential for Hematopoiesis. J Stem Cell Res Ther 8: 441. doi: 10.4172/2157-7633.1000441

Copyright: (c) 2018 Raghav PK, et al. This is an open-access article distributed under the terms of the Creative Commons Attribution License, which permits unrestricted use, distribution, and reproduction in any medium, provided the original author and source are credited. 
Citation: Raghav PK, Gangenahalli G (2018) Hematopoietic Stem Cell Molecular Targets and Factors Essential for Hematopoiesis. J Stem Cell Res Ther 8: 441. doi: 10.4172/2157-7633.1000441

Page 2 of 16

Hence, this review focuses on understanding the molecular targets and factors, their interactions that are involved in controlling hematopoiesis.

\section{Hematopoiesis}

HSCs are capable of hematopoiesis and further subdivided into Short-Term HSCs (ST-HSCs) and Long-Term HSCs (LT-HSCs) [14]. These cells are different from other CFU or Multipotent Progenitors (MPPs) as they possess the distinct repopulating ability. LT-HSCs are renowned for their extensive self-renewal capacity, whereas the STHSCs have less self-renewal capacity but possess higher differentiation potential. In hematopoiesis, HSCs produce every lineage including red blood cells, platelets, and various lymphoid and myeloid cells. The lymphoid cells further differentiate into Natural Killer (NK) cells, T-cells, and B-cells, while myeloid cells differentiate into granulocytes, monocytes, macrophages, microglial cells, and dendritic cells [15]. The hematopoietic hierarchy begins with HSCs that differentiate into lineage-restricted progenitors and terminally differentiated cells [1621]. The differentiation and proliferation of HSCs are regulated by cytokines and their respective receptors, and transcription factors. Besides, we collect the freely available databases/datasets providing information of transcriptomic, genomic data, and clinical resources in the area of hematopoiesis (Table 1). The 76 articles were obtained from PUBMED by using the search term "databases of hematopoiesis" from title or abstract.

\section{Role of cytokines and their receptors in hematopoiesis}

Cytokines interact with their respective receptors on both pluripotent and committed progenitor stem cells to regulate proliferation, and differentiation (Figure 1). This binding triggers the downstream signaling which results in the translocation of transcription factors from the cytoplasm to the nucleus. These transcription factors interact with other cell-specific transcription factors and regulate the self-renewal property of HSCs. Another level of competition and control is provided by chromatin-associated factors, such as MLL and BMI1 [22].

Cytokines manipulate the culture conditions by inducing selective gene expression in stem cells to proliferate, self-renew or differentiate into lineage-specific cell type [23]. The cytokines that play an essential role in hematopoiesis are listed in Table 2. The CSFs induce the multipotent hematopoietic progenitors and pluripotent HSC

\begin{tabular}{|c|c|c|c|}
\hline S. No. & Database & Description/Link & PMID \\
\hline 1 & BloodChIP & $\begin{array}{l}\text { Explore transcription factor sites in human CD34+ and other healthy and leukemic cells based on ChIP-seq } \\
\text { data. http://www.med.unsw.edu.au/CRCWeb.nsf/page/BloodChIP }\end{array}$ & 24185696 \\
\hline 2 & BloodSpot & $\begin{array}{l}\text { Provide gene expression profiles of healthy and malignant hematopoiesis in human or mice samples. http:// } \\
\text { www.bloodspot.eu }\end{array}$ & 26507857 \\
\hline 3 & CODEX & $\begin{array}{l}\text { A database specialized for grouping NGS data of human and mouse HSCs. http://codex.stemcells.cam. } \\
\text { ac.uk }\end{array}$ & 25270877 \\
\hline 4 & database R2 & Genomics Analysis and Visualization Platform of hematopoietic factors. http://r2.amc.nl & 29449653 \\
\hline 5 & DBA mutation database & $\begin{array}{l}\text { Integrating information on Diamond-Blackfan Anemia (DBA) mutation and frequency at DNA, RNA, and } \\
\text { protein level. http://www.dbagenes.unito.it }\end{array}$ & 20960466 \\
\hline 6 & $\mathrm{dbRBC}$ & $\begin{array}{l}\text { A database of human RBCs for DNA and clinical data. http://www.ncbi.nlm.nih.gov/projects/gv/rbc/main. } \\
\text { fcgi?cmd= nit }\end{array}$ & 22084196 \\
\hline 7 & ErythronDB & Providing the expression profile of murine erythroid cells. http://www.cbil.upenn.edu/ ErythronDB & 23243273 \\
\hline 8 & European LeukemiaNet & $\begin{array}{l}\text { Possessed physicians and patients information about diagnosis, treatment, and ongoing clinical trials. } \\
\text { http://www.leukemia-net.org/content/home/index_eng. } \mathrm{Html}\end{array}$ & 23803709 \\
\hline 9 & ExAC & $\begin{array}{l}\text { Exome Aggregation Consortium (ExAC), a database for clinical interpretation of genetic variants aggregate } \\
\text { and harmonize exome sequencing. http://exac.broadinstitute.org/ }\end{array}$ & 28229513 \\
\hline 10 & Hembase & Integrating sequencing data of ESTs of human erythroid cells. http://hembase.niddk.nih.gov/ & 14681483 \\
\hline 11 & HemoPDB & $\begin{array}{l}\text { Hematopoiesis promoter database, an information resource of transcriptional regulation in blood cell } \\
\text { development. http://bioinformatics.med.ohio-state.edu/HemoPDB }\end{array}$ & 14681365 \\
\hline 12 & HSC-Explorer & Contains hematopoiesis information. http://mips.helmholtz-muenchen.de/HSC/ & 23936191 \\
\hline 13 & JASPAR database & Transcription Factor binding profiles. http://jaspar.genered.net & 30013175 \\
\hline 14 & KEGG database & $\begin{array}{l}\text { KEGG (Kyoto Encyclopedia of Genes and Genomes), a database for biological interpretation of genome } \\
\text { sequences and other high-throughput data. https://www.kegg.jp/ }\end{array}$ & 30321428 \\
\hline 15 & Leukemia Gene Atlas & $\begin{array}{l}\text { Integrating microarray, DNA methylation, SNP, and high-throughput sequencing datasets of approximately } \\
5800 \text { leukemia and hematopoiesis samples. http://www.leukemia-gene-atlas. org/LGAtlas }\end{array}$ & 22720055 \\
\hline 16 & LeukoStage Database & $\begin{array}{l}\text { The qPCR data of gene expression in malignant and non-malignant cells of different lineages. http:// } \\
\text { camelot.If2.cuni.cz/fiserkar/LSDat/gens2/index.php }\end{array}$ & 26674556 \\
\hline 17 & MicroRNA.org & Resource of microRNA target predictions and expression profiles. www.microrna.org & 18158296 \\
\hline 18 & miRBase Targets & microRNA sequence repository of several species. http://microrna.sanger.ac.uk/targets/v3 & 24275495 \\
\hline 19 & NetPath & $\begin{array}{l}\text { Reaction map of RANKL plays a role in hematopoiesis with bone remodeling. http://www.netpath.org/ } \\
\text { pathways?path_id=NetPath_21 }\end{array}$ & 21742767 \\
\hline 20 & $\begin{array}{|lr|}\text { Red Cell } & \text { Membrane } \\
\text { Disorder } & \text { Mutations } \\
\text { Database } & \\
\end{array}$ & $\begin{array}{l}\text { Gene mutation data of the erythrocyte membrane associated with hemolytic anemia. http://research.nhgri. } \\
\text { nih.gov/RBCmembrane }\end{array}$ & 18341630 \\
\hline 21 & SBR-Blood & $\begin{array}{l}\text { Hematopoietic systems biology repository contains datasets for array and sequencing-based platforms } \\
\text { from mouse hematopoietic cells. http://sbrblood.nhgri.nih.gov }\end{array}$ & 26590403 \\
\hline 22 & $\mathrm{SCDb}$ & Transcription factors stem cell database. http://stemcell.princeton.edu & 12070015 \\
\hline 23 & StroCDB & $\begin{array}{l}\text { Stromal Cell Database of biological and molecular studies of the surrogate niche. http://stromalcell. } \\
\text { princeton.edu }\end{array}$ & 15492413 \\
\hline 24 & TargetScan & miRNA target prediction data in mammals. www.targetscan.org & 26267216 \\
\hline
\end{tabular}

Table 1: Databases of hematopoiesis. 
Citation: Raghav PK, Gangenahalli G (2018) Hematopoietic Stem Cell Molecular Targets and Factors Essential for Hematopoiesis. J Stem Cell Res Ther 8: 441. doi: 10.4172/2157-7633.1000441

Page 3 of 16

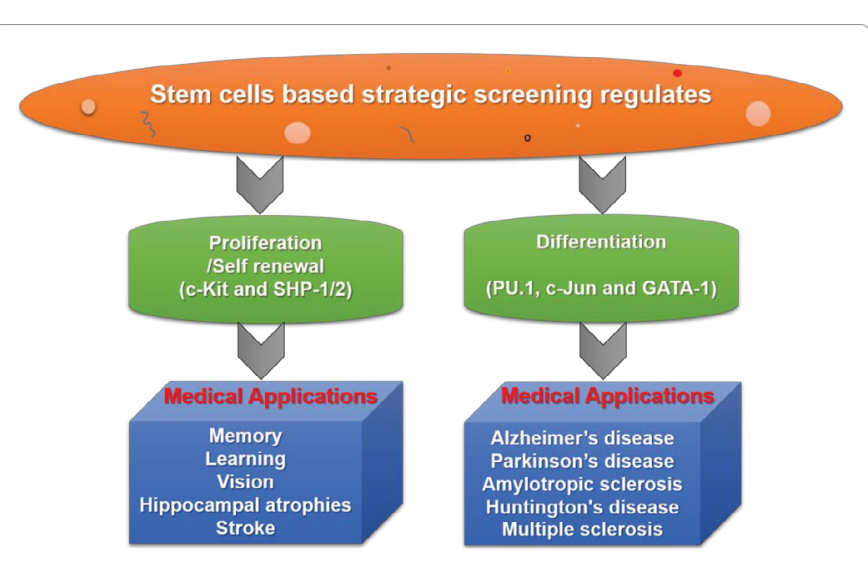

Figure 1: Essential properties of stem cells and their potential medical applications. differentiation [24]. The CSFs are named depending on the fate of lineage formed which includes Erythropoietin (EPO), TPO, GM-CSF G-CSF, and Macrophage-CSF (M-CSF). These cytokines have been grouped into four families, based on their signal transducing subunits:

1.) Homodimerizing

2.) Heterodimerizing

3.) Interferon family

4.) Tyrosine kinase receptors

The homodimerizing receptors belong to the same homodimeric type I subfamily of cytokine receptors, G-CSF-R, EPO-R, and TPO-R.

The heterodimerizing receptors have been classified into gp130 receptor family (IL6-R $\alpha$, LIF-R $\beta$, IL11-Ra, Oncostatin M-R $\alpha$, CNTF$\mathrm{R} \alpha$, and CLCF-R); common $\beta$ receptor $(\beta c)$ family (GM-CSFR $\alpha$, IL3-

\begin{tabular}{|c|c|c|c|}
\hline S. No. & Cytokines/ signaling & Role & PMID \\
\hline 1 & Activin A & Production within bone marrow regulates of steady-state hematopoiesis. & 1426103 \\
\hline 2 & bFGF or FGF-2 & $\begin{array}{l}\text { A potent hematopoietic growth factor, plays an important role in physiological and } \\
\text { pathological hematopoiesis. }\end{array}$ & 8714368 \\
\hline 3 & CXCL12/SDF-1 & $\begin{array}{l}\text { CXCL12 did not induce signaling through CXCR7, but formed functional heterodimers } \\
\text { with CXCR4 and enhanced CXCL12-induced signaling in endothelial biology and valve } \\
\text { development }\end{array}$ & 17804806 \\
\hline 4 & EPO & Stimulates the proliferation and terminal maturation of CFU-E and BFU-E & 7553874 \\
\hline 5 & FLT3 & $\begin{array}{l}\text { An angiogenic marker in multiple myeloma patients. Regulates proliferation and survival of } \\
\text { MPP. }\end{array}$ & 26521986,26521986 \\
\hline 6 & G-CSF and GM-CSF & Both accelerate the recovery of normal granulopoiesis. & 12069373 \\
\hline 7 & G-CSF and M-CSF & $\begin{array}{l}\text { Act on more mature cells of the same lineage and are only required later during the } \\
\text { differentiation of cell lineage. }\end{array}$ & 7534912 \\
\hline 8 & GM-CSF & $\begin{array}{l}\text { Induced proliferative stimulus to enhance platelet production, plays a role in } \\
\text { megakaryocytopoiesis, and myelomonocytic lineage. Regulates cell metabolic activity, } \\
\text { specifically by promoting glucose uptake. }\end{array}$ & $1825794,7534912,27236376$ \\
\hline 9 & $\begin{array}{l}\text { IFNy and myelosuppressive } \\
\text { cytokine receptors }\end{array}$ & $\begin{array}{l}\text { PKR (protein kinase R) plays essential roles in IFNy signaling as a common mediator of } \\
\text { signals for hematopoietic suppression. }\end{array}$ & 21659535 \\
\hline 10 & IFN- $y$, TNF- $\alpha$, and IL-6 & $\begin{array}{l}\text { Contribute to the anemia in lymphoma, and elevated EPO and EPOR levels balanced } \\
\text { negative regulatory effects on hematopoiesis to maintain normal hematopoiesis. }\end{array}$ & 23628039,25440916 \\
\hline 11 & $\begin{array}{l}\text { IL 1, IL 6, and tumor necrosis } \\
\text { factor (TNF) }\end{array}$ & Involved in the regulation of the immune response, hematopoiesis, and inflammation, etc. & $\begin{array}{l}2199284,10851053,9867112 \\
8630372,19229053\end{array}$ \\
\hline 12 & IL-1 $1 \alpha$, IL-3, IL-6, and GM-CSF. & Role in erythropoiesis and megakaryopoiesis & 7792269 \\
\hline 13 & IL-2 and TNF- $\alpha$ & Role in the control of normal hematopoiesis and leukemogenesis. & 1999955 \\
\hline 14 & IL-27 & Regulates immune responses as well as hematopoiesis and bone remodeling. & 27677834 \\
\hline 15 & IL-2Ryc & $\begin{array}{l}\text { The IL-2 receptor y common chain is the shared subunit of the receptors for the IL-2 family } \\
\text { of cytokines, which mediate signaling through JAK3 pathways to regulate lymphopoiesis } \\
\text { and erythropoiesis. }\end{array}$ & 26590317,26404745 \\
\hline 16 & IL-3 & Activates Jak2 signaling by c-Abl in 32D hematopoietic cells. & 24923444 \\
\hline 17 & IL-3 and GM-CSF & $\begin{array}{l}\text { Promotes a modest increase in Ca2+, plays a role in hematopoiesis, especially on certain } \\
\text { cell subsets, basophil and mast cells, and alveolar macrophages. }\end{array}$ & $22201962,18775989,9664156$ \\
\hline 18 & IL-33 & Triggers pathogenesis of myeloproliferative neoplasms and have a role in innate immunity. & 26011644,20643815 \\
\hline 19 & IL-5 & $\begin{array}{l}\text { Released from T lymphocytes of mammals infected with microorganisms or parasites, plays } \\
\text { a role in hematopoiesis. }\end{array}$ & 1365906 \\
\hline 20 & SCF & Increase the survival, self-renewal, and maintenance of HSCs & $27365423,11067877,25100529$ \\
\hline 21 & SDF-1/CXCR4 & $\begin{array}{l}\text { Signaling promotes restoration of hematopoiesis by regulating the homing and engraftment } \\
\text { of MSCs and HSPCs. }\end{array}$ & 17606439,21186999 \\
\hline 22 & TGF- $\beta$ and bFGF & $\begin{array}{l}\text { Pathogenesis of idiopathic myelofibrosis. Also, regulates cell proliferation, differentiation, } \\
\text { apoptosis, migration, and extracellular matrix production. }\end{array}$ & $11317961,9477133,12428417$ \\
\hline 23 & TNF- $\alpha$ & $\begin{array}{l}\text { Induces extrinsic apoptosis and necroptosis of hematopoietic cells. A proinflammatory } \\
\text { cytokine produced by macrophages plays an important role in inflammation and immune } \\
\text { response. }\end{array}$ & $26149913,27358858,23720862$ \\
\hline 24 & TPO & $\begin{array}{l}\text { Regulates the expansion and maturation of megakaryocytes. Also, contributes to the } \\
\text { formation and the maintenance of hematopoietic cell clusters in the AGM (aorta-gonad- } \\
\text { mesonephros) region. }\end{array}$ & 10786657,28235674 \\
\hline 25 & TPO and G-CSF receptors & In vivo role in hematopoietic cell fate decisions. & 9892696 \\
\hline
\end{tabular}

Table 2: Role of cytokines and their receptors in hematopoiesis. 
Citation: Raghav PK, Gangenahalli G (2018) Hematopoietic Stem Cell Molecular Targets and Factors Essential for Hematopoiesis. J Stem Cell Res Ther 8: 441. doi: 10.4172/2157-7633.1000441

Page 4 of 16

Ra, and IL5-R $\alpha$ ); and IL2-R family ( $\gamma$ chain) (includes IL4-R $\alpha$, IL7-R $\alpha$, IL9-Ra, IL13-Ra, IL15-Ra, and IL21-Ra).

The interferon family comprises of IFN- $\alpha$, IFN $\gamma$-R1/2, and IL10-R1/2 receptors whereas, tyrosine kinase receptors consist of FMSlike Tyrosine kinase 3 (FLT3) and c-Kit receptor [25].

These receptors are activated by three major pathways such as the JAK-STAT pathway, the p38 Mitogen-Activated Protein Kinase (MAPK) pathway, and the Phosphoinositide 3-Kinase (PI3K)/AKT pathway. Besides other pathways like NF- $\mathrm{B}, \mathrm{TGF} / \mathrm{SMAD}$, and Protein Kinase $\mathrm{C}(\mathrm{PKC})$ plays an essential role in regulating hematopoiesis and hematologic malignancies [26-29]. On the contrary, Tumor Growth Factor-beta (TGF $\beta$ ), Tumor Necrosis Factor-alpha (TNF $\alpha$ ), and Interferons (IFNs) are negative regulators of hematopoiesis and represent attractive drug targets [30]. Figure 2 shows the growth factors that play roles in the differentiation of HSCs. The SCF and FLT3 ligand bind with c-Kit and FLT-3 tyrosine kinase receptors, respectively which influence the proliferation individually and differentiation synergistically in CD34+ and CD38- progenitor cells [31]. Also, the synergistic effect of SCF with multiple cytokines in differentiation regulates BCL-2, BCL-XL, and perhaps other anti-apoptotic molecules, targeted to promote cell survival [32]. These receptors are essential targets for their down-regulation during normal differentiation.

\section{Role of transcription factors in hematopoiesis}

Transcription factors interact with the regulatory region of genes, either alone or in complex with co-activator to increase or decrease expression of genes [33]. The transcriptional network plays a crucial regulatory function in proliferation and differentiation in HSCs to become specialized into distinct blood cell lineage [34]. The Expression of lineage-affiliated transcription factors along with a simple hierarchy of hematopoiesis is shown in Figure 2. Several transcription factors, directly and indirectly, played a crucial role in regulating hematopoiesis (Table 3). Also, these transcription factors which regulate hematopoiesis have been discussed in single and multiple studies.

There are three key transcription factors, PU.1 and c-Jun, and GATA-1 which regulate myelopoiesis and erythropoiesis respectively (Figure 3) [35,36]. PU.1 also interacts synergistically or antagonistically with c-Jun, C/EBP $\delta$, GATA-1, GATA-2, C/EBPa, c-Myb, CBP, AML-1B, AML-1/ETO, NF-EMS/Pip/IRF-4, and ICSBP/IRF-8, which governs most of the genes [37-47]. According to the classification of transcription factors, PU.1 (molecular weight $31 \mathrm{kDa}$ ) protein is encoded by SPI1 gene located on chromosome2 (mouse) or chromosome11 (human), related

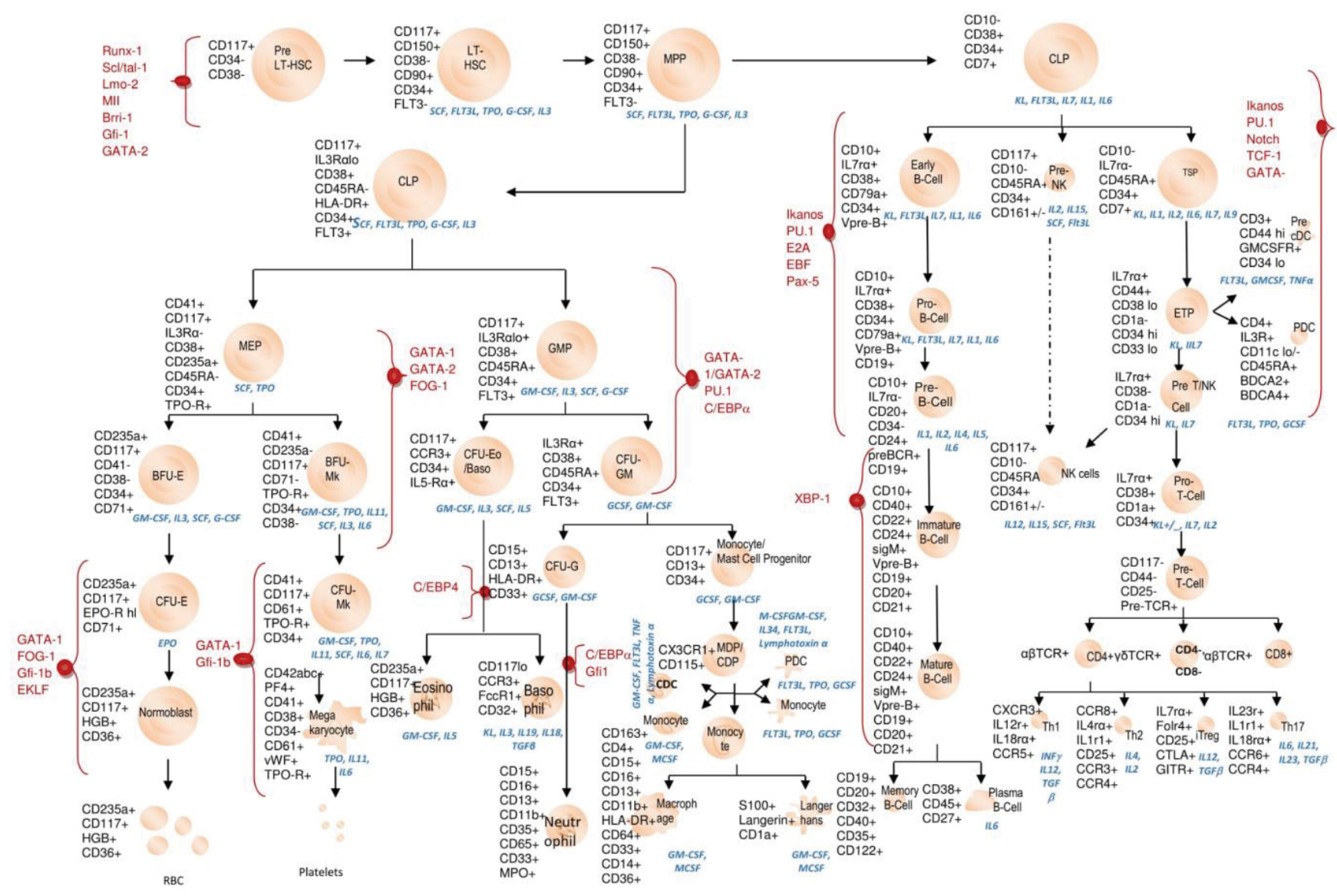

Figure 2: Hematopoiesis represents HSCs differentiation into erythrocytes, thrombocyte, basophils, eosinophils, neutrophils, monocyte, dendritic, NK cells, and B-lymphocytes and T-lymphocytes.

PDC: Plasma Dendritic Cells; CDC: Conventional Dendritic Cell; Monocyte 1: CD64+, CD14+, CD16+; Monocyte 2: CD64+, CD14+ CD16-; Monocyte 3: CD64-, CD14+, CD16+ 
Citation: Raghav PK, Gangenahalli G (2018) Hematopoietic Stem Cell Molecular Targets and Factors Essential for Hematopoiesis. J Stem Cell Res Ther 8: 441. doi: 10.4172/2157-7633.1000441

Page 5 of 16

\begin{tabular}{|c|c|c|c|}
\hline S. No. & TF & Role & PMID \\
\hline 1 & AF10 & $\begin{array}{l}\text { AF10 is important for proper hematopoietic differentiation. AF10 plays a key role in the maintenance of } \\
\text { multipotent hematopoietic cells. }\end{array}$ & 23284727 \\
\hline 2 & AHR & $\begin{array}{l}\text { Aryl Hydrocarbon Receptor (AHR) known to regulate cellular responses to oxidative stress and inflammation } \\
\text { through transcriptional regulation of molecules involved in the signaling of nuclear factor-erythroid 2-related } \\
\text { factor-2 (Nrf2), p53 (TRP53), retinoblastoma (RB1), and NFkB. }\end{array}$ & $\begin{array}{ll}22628113, & 18983985, \\
19896476\end{array}$ \\
\hline 3 & AML1 & AML1 transcription factor is a critical regulator of normal hematopoiesis. & $\begin{array}{ll}11368373, & 11721960, \\
12946863, & 19813271, \\
19151769, & 10200536, \\
12643014, & 9778047 \\
\end{array}$ \\
\hline 4 & $\begin{array}{l}\text { AML1, C/EBPa, HOX, and } \\
\text { GATA family }\end{array}$ & All these transcription factors play an important role in hematopoiesis & 18766960,10557039 \\
\hline 5 & $\begin{array}{l}\text { AML1, C/EBPa, RARa, } \\
\text { MOZ, p300/CBP, and MLL }\end{array}$ & All of which are important in the regulation of hematopoiesis. & 21823042 \\
\hline 6 & $\begin{array}{l}\text { AML1/PEBP2 } \alpha \text { B/CBFa2 } \\
\text { gene or PEBP2 } \beta / C B F b\end{array}$ & PEBP2/CBF plays an important role in angiogenesis. & 10644985 \\
\hline 7 & AP-1 & $\begin{array}{l}\text { Activator protein-1 (AP-1) regulates a wide range of cellular processes including proliferation, differentiation, } \\
\text { and apoptosis. }\end{array}$ & 22822070 \\
\hline 8 & BATF & TF BATF is essential for an initial commitment of naive CD8(+) T cells to effector development. & 25548173 \\
\hline 9 & Biklf & A krüppel-like transcription factor is preferentially required for erythroid cell differentiation in zebrafish. & 11553329 \\
\hline 10 & C/EBPa & $\begin{array}{l}\text { CCAAT/enhancer binding protein } \alpha(\mathrm{C} / \mathrm{EBP} \alpha) \text { is involved in the myeloid development and indispensable for } \\
\text { the formation of granulocytes. }\end{array}$ & $\begin{array}{l}20807890, \quad 26511037, \\
24561082,17217039\end{array}$ \\
\hline 11 & C/EBP $\beta$ & $\begin{array}{l}\text { CCAAT/enhancer-binding protein } \beta(C / E B P \beta) \text { transcription factor is required for stress-induced } \\
\text { granulopoiesis, whereas C/EBPa plays a critical role in maintaining steady-state granulopoiesis. }\end{array}$ & $\begin{array}{lr}25940801, & 9637691, \\
9637691, & 29973462, \\
25448741 & \end{array}$ \\
\hline 12 & CBF $\beta$ & $\begin{array}{l}\text { Core Binding Factor } \beta(C B F \beta) \text { is complexed with the RUNX family of transcription factors in the nucleus } \\
\text { to support activation or repression of genes related to bone (RUNX2), hematopoiesis (RUNX1) and } \\
\text { gastrointestinal (RUNX3) development. }\end{array}$ & 24648201,20195544 \\
\hline 13 & $C d x$ & Cdx genes $(C d \times 1, C d \times 2$, and $C d x 4)$ is involved during embryonic hematopoiesis in the mouse. & 18511567 \\
\hline 14 & Cf-ETS & $\begin{array}{l}\text { CDNA encoding a putative ETS transcription factor, play indispensable roles in blood cell differentiation and } \\
\text { linage commitment during hematopoiesis. CF-ETS is a potential biomarker for hematopoiesis studies in sea } \\
\text { scallop Chlamys farreri. }\end{array}$ & 19446578 \\
\hline 15 & c-fos & $\begin{array}{l}\text { c-fos or GATA-1, which could pay the role in the Ginsenosides (GS) induced up-regulation correlated with } \\
\text { proliferation and differentiation of hematopoiesis. }\end{array}$ & 12577377 \\
\hline 16 & c-Maf & $\begin{array}{l}\text { c-Maf is one of the large Maf (musculoaponeurotic fibrosarcoma) is crucial for definitive erythropoiesis in } \\
\text { the fetal liver. }\end{array}$ & 21628412 \\
\hline 17 & c-Myb & Regulating hematopoietic cell proliferation and cytokines synthesis by bone marrow fibroblasts. & $\begin{array}{lr}20823231, & 8643572, \\
7688794, & 19955420, \\
18585056, & 16597594 \\
8643572, & 21960247 \\
11290610, & 8084617 \\
18187733, & 24257756\end{array}$ \\
\hline 18 & CREB & $\begin{array}{l}\text { Cyclic-AMP response element binding protein (CREB) functions in glucose homeostasis, growth-factor- } \\
\text { dependent cell survival, proliferation, and memory. CREB acts as a proto-oncogene to regulate hematopoiesis } \\
\text { and contributes to the leukemia phenotype. }\end{array}$ & $\begin{array}{l}16096372, \quad 15837624, \\
19960054,16196046, \\
17975014,16819137\end{array}$ \\
\hline 19 & CUX1 & $\begin{array}{l}\text { Homeodomain-containing transcription factor knockdown promotes PI3K signaling, drives HSC exit from } \\
\text { quiescence and proliferation, and results in HSC exhaustion }\end{array}$ & 29592892 \\
\hline 20 & Ebf2 & $\begin{array}{l}\text { Early B cell factor } 2 \text { (Ebf2), acts as a transcriptional determinant of an osteoblastic niche that regulates the } \\
\text { maintenance of hematopoietic progenitors, in part by modulating Wnt signaling. }\end{array}$ & 20887955,20887955 \\
\hline 21 & EKLF & Eklf expression defines a novel role for Eklf as a regulator of lineage fate decisions during hematopoiesis. & $\begin{array}{l}17715392, \quad 18448565, \\
18448565\end{array}$ \\
\hline 22 & ERG & $\begin{array}{l}\text { ETS factor, ERG, has emerged as a key player in normal hematopoiesis. Critical regulator of adult HSCs, } \\
\text { essential for maintaining self-renewal during HSC cycling. }\end{array}$ & $\begin{array}{ll}21664289, & 19487285 \\
23719302, & 29050203, \\
21673349 & \end{array}$ \\
\hline 23 & ESE-1 & $\begin{array}{l}\text { ETS family of transcription factors regulates cell proliferation, cell differentiation, embryonic development, } \\
\text { neoplasia, hematopoiesis, angiogenesis, and inflammation. }\end{array}$ & 22157719 \\
\hline 24 & Etv2 & ETS domain transcription factor is an essential regulator of vasculogenesis and hematopoiesis. & 22406820 \\
\hline 25 & Evi1 & $\begin{array}{l}\text { Ecotropic viral integration site- } 1 \text { is an oncogenic transcription factor in murine and human myeloid leukemia. } \\
\text { Evi1 targets the GATA-2 for the transcription factors which regulates the HSC pool hierarchically. }\end{array}$ & $\begin{array}{l}15889140,15889140, \\
20842122,19385966\end{array}$ \\
\hline 26 & Fli-1 & Regulates hematopoiesis and hemostasis. & $\begin{array}{l}10891501, \quad 17688409, \\
28586009\end{array}$ \\
\hline 27 & Fli-3 & $\begin{array}{l}\text { Fli-3 encoding mir-17-92 involved in the development of erythroleukemia and its important role in } \\
\text { hematopoiesis. }\end{array}$ & 17586726 \\
\hline 28 & Foggy/Spt5 & $\begin{array}{l}\text { Negatively and positively regulates transcription elongation. Plays an important role in GATA-1 gene } \\
\text { expression and erythropoiesis through its transcriptional activation domain. }\end{array}$ & 21205096 \\
\hline 29 & FOXM1 & $\begin{array}{l}\text { Forkhead box M1belongs to the forkhead/winged-helix family of transcription factors and regulates a network } \\
\text { of proliferation-associated genes. }\end{array}$ & 28154085 \\
\hline 30 & FOXO3 & Forkhead transcription factor 3 plays role in development, aging, and, in longevity. & $\begin{array}{l}24747665,26084022, \\
18371339\end{array}$ \\
\hline
\end{tabular}


Citation: Raghav PK, Gangenahalli G (2018) Hematopoietic Stem Cell Molecular Targets and Factors Essential for Hematopoiesis. J Stem Cell Res Ther 8: 441. doi: 10.4172/2157-7633.1000441

Page 6 of 16

\begin{tabular}{|c|c|c|c|}
\hline 31 & GABP & $\begin{array}{l}\text { Necessary for stem/progenitor cell maintenance and myeloid differentiation in human hematopoiesis and } \\
\text { chronic myeloid leukemia. }\end{array}$ & 27100840 \\
\hline 32 & GATA & $\begin{array}{l}\text { Essential for the development of endoderm during embryogenesis and the renewal of the differentiated } \\
\text { epithelium in the mature gut. GATA- } 1 \text {, one of the hematopoietically expressed members, is required for } \\
\text { normal erythroid and megakaryocytic differentiation. GATA-2 crucial for the proliferation and maintenance of } \\
\text { hematopoietic stem cells and multipotential progenitors. GATA-4/5/6 functions in a common pathway, at the } \\
\text { time of cardiac crescent formation, for regulating early embryonic cardiac morphogenesis. }\end{array}$ & $\begin{array}{lr}24436352, & 9657742, \\
26445707, & 23371459, \\
21605981, & 22492510, \\
8643572, & 11146164, \\
8643572, & 16158817, \\
9657742, & 15659348, \\
16144799, & 12577377, \\
17688409, & 23241114, \\
7738198, & 9621433 \\
8045339, & 21788913\end{array}$ \\
\hline 33 & Gfi1 and Gfi1b & DNA-binding zinc finger transcription factors Gfi1 and Gfi1b, regulators of both early hematopoiesis. & $\begin{array}{ll}26447191, & 20190815, \\
12351384, & 12351384, \\
20190815, & 17646546, \\
18504458, & 19164764, \\
20453161, & 25398765\end{array}$ \\
\hline 34 & Hhex & Key regulator of early lymphoid development, functioning, at least in part, via regulation of the cell cycle. & $\begin{array}{l}25472970, \quad 25472970, \\
29263042\end{array}$ \\
\hline 35 & HIF-1 and HIF-2 & $\begin{array}{l}\text { Hypoxic signaling plays an essential role in maintaining oxygen homeostasis and cell survival. Role in } \\
\text { the regulation of skeletal development, bone formation, and regeneration, as well as joint formation and } \\
\text { homeostasis. }\end{array}$ & 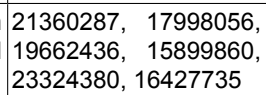 \\
\hline 36 & HLA-G & HLA-G transcription indicated a contribution to the tumoral progression by blocking natural killing reaction. & 8988550,8795141 \\
\hline 37 & HLF & $\begin{array}{l}\text { Transcription factor hepatic leukemia factor, HLF as a critical regulator of HSC quiescence and as an } \\
\text { essential factor for maintaining the HSC pool during regeneration. }\end{array}$ & 29262330 \\
\hline 38 & Hmga2 & Hmga2 as a transcriptional target of RUNX1 and a critical regulator of myeloid progenitor expansion. & 25150295 \\
\hline 39 & HOXA9 & $\begin{array}{l}\text { HOXA9 plays a critical role in both normal hematopoiesis and leukemogenesis, particularly in the } \\
\text { development and maintenance of mixed lineage leukemia (MLL)-rearranged leukemia. }\end{array}$ & 22633751,14604967 \\
\hline 40 & HOXB10 & Regulation of HOXA10 expression in megakaryocytic differentiation. & 17688409 \\
\hline 41 & Hoxb4 & $\begin{array}{l}\text { Overexpression promotes the dramatic expansion of bone marrow HSCs without leukemic transformation } \\
\text { and induces development of definitive HSCs from the early embryonic yolk sac. }\end{array}$ & $\begin{array}{l}21278354,14962901 \\
15854307,17761289\end{array}$ \\
\hline 42 & HOXB6 & $\begin{array}{l}\text { In vitro, HOXB6 immortalized a factor-dependent myelomonocytic precursor capable of granulocytic and } \\
\text { monocytic differentiation. }\end{array}$ & 15522959, 10996827 \\
\hline 43 & HOXB7 & $\begin{array}{l}\text { HOX family of homeobox transcription factors plays a role in the proliferation and differentiation of primary } \\
\text { hematopoietic cells. }\end{array}$ & 11290787 \\
\hline 44 & HPIP & $\begin{array}{l}\text { Hematopoietic pre-B-cell leukemia transcription factor-interacting protein (HPIP) is a corepressor of pre-B- } \\
\text { cell leukemia homeobox (PBX) } 1 \text { and is known to play a role in hematopoiesis. }\end{array}$ & 25060351 \\
\hline 45 & ICSBP & $\begin{array}{l}\text { Interferon consensus sequence binding protein (ICSBP), novel role in regulating the proliferation and } \\
\text { differentiation of hematopoietic progenitor cells. }\end{array}$ & 8861914 \\
\hline 46 & Ikaros & $\begin{array}{l}\text { Ikaros family of proteins- comprising Ikaros, Aiolos, Helios, Eos, and Pegasus - are zinc finger transcription } \\
\text { factors regulate important cell-fate decisions during hematopoiesis, particularly in the development of the } \\
\text { adaptive immune system. }\end{array}$ & 21477865 \\
\hline 47 & Jumu & Jumeau (Jumu), controls the hemocyte differentiation of lymph gland through multiple regulatory mechanisms. & 28350299 \\
\hline 48 & KLF4 & $\begin{array}{l}\text { Krüppel-like factor } 4 \text { is a zinc finger protein with dual functions that can act as a transcriptional activator and } \\
\text { repressor of genes involved in cell proliferation, differentiation, and apoptosis and regulates the development } \\
\text { and function of the myeloid and lymphoid blood lineages. }\end{array}$ & 26908828,26908828, \\
\hline 49 & Klf6 & $\begin{array}{l}\text { Krüppel-like factor } 6 \text { (Klf6; copeb in zebrafish), copeb/KIf6 is essential for the development of endoderm- } \\
\text { derived organs. }\end{array}$ & 20430021 \\
\hline 50 & LEF1 & $\begin{array}{l}\text { Lymphoid enhancer-binding factor } 1 \text { plays a crucial role in the maintenance, proliferation, and differentiation } \\
\text { of normal hematopoietic stem/progenitor cells. }\end{array}$ & 26117056 \\
\hline 51 & LMO2 & $\begin{array}{l}\text { LIM domain only } 2 \text { regulates hematopoiesis and vascular development, endothelial proliferation and } \\
\text { angiogenesis. }\end{array}$ & 27792641,27779255 \\
\hline 52 & MEF & $\begin{array}{l}\text { Myeloid Elf- } 1 \text { like factor plays a critical role in NK and NK-T cell development and the constitutive expression } \\
\text { of perforin by NK cells. }\end{array}$ & 14636650 \\
\hline 53 & MEF2C & Myocyte enhancer factor $2 \mathrm{C}$ identified as an essential regulator of muscle development and hematopoiesis. & 23435431 \\
\hline 54 & meis1 & Meis1, jointly with pbx1, regulates primitive hematopoiesis as well as vascular development in zebrafish & 21048033 \\
\hline 55 & MLF1 & $\begin{array}{l}\text { Myeloid Leukemia Factor plays an important role in hematopoiesis and leukemia, notably by regulating the } \\
\text { stability of RUNX transcription factors. }\end{array}$ & 22885977,22411814 \\
\hline 56 & $\begin{array}{l}\text { Monocytic Leukemia zinc } \\
\text { finger (MOZ) }\end{array}$ & $\begin{array}{l}\text { Role of MOZ-driven acetylation in controlling a desirable balance between proliferation and differentiation } \\
\text { during hematopoiesis. }\end{array}$ & 19264921 \\
\hline 57 & Mxd4 & Regulates proliferation of blood progenitor. & 21782766,21782766 \\
\hline 58 & $\begin{array}{l}\text { Myc, USF, TFII-I, and } \\
\text { Tal11/SCL }\end{array}$ & $\begin{array}{l}\text { Function sequentially, cooperatively, or antagonistically in regulating expression programs during the } \\
\text { differentiation of erythroid cells. }\end{array}$ & 21282467,21779460 \\
\hline 59 & MYCN (N-Myc) & $\begin{array}{l}\text { MYCN reprograms hematopoietic cell fate by regulating NDRG1 and several lineage-specific hematopoietic } \\
\text { transcription factors. }\end{array}$ & 23554972, 23554972 \\
\hline 60 & $\begin{array}{l}\text { Myeloid zinc finger } 1 \\
\text { (MZF1) }\end{array}$ & $\begin{array}{l}\text { MZF1 expression interfered with the ability of embryonic stem cells to undergo hematopoietic commitment } \\
\text { and erythromyeloid colony formation and prevented the induced expression of CD34 and c-Myb mRNAs } \\
\text { during differentiation }\end{array}$ & 25436607 \\
\hline 61 & NANOG, OCT4, and SOX2 & Pluripotent factors expression in and pluripotency of hESCs is maintained by Tip110. & 22132941 \\
\hline
\end{tabular}


Citation: Raghav PK, Gangenahalli G (2018) Hematopoietic Stem Cell Molecular Targets and Factors Essential for Hematopoiesis. J Stem Cell Res Ther 8: 441. doi: 10.4172/2157-7633.1000441

Page 7 of 16

\begin{tabular}{|c|c|c|c|}
\hline 62 & NFATc2 & Plays a role in the maintenance of steady-state hematopoiesis and bone remodeling in adult organisms. & 21750088 \\
\hline 63 & NF-E2 & Role in Megakaryocyte Maturation and Platelet Production & 10355135,16860008 \\
\hline 64 & NF-E2 & NF-E2 plays role in differentiation of megakaryocytes and erythrocytes. & 10556187 \\
\hline 65 & Nfil3 & $\begin{array}{l}\text { Functions in immune cells as key regulator of CD8a(+) dendritic cell and natural killer cell development in } \\
\text { mice. Enriched in the myeloid compartment of adult zebrafish including eosinophils. }\end{array}$ & 22561072 \\
\hline 66 & Nfix & Early B lymphopoiesis and myelopoiesis. & 25780920 \\
\hline 67 & NFIX & Nuclear Factor One X (NFIX) & 30287093 \\
\hline 68 & NF-Ya & NF-Ya is a potent cellular regulator of HSC self-renewal. & 16081537 \\
\hline 69 & NRF2 & $\begin{array}{l}\text { Appropriate control of NRF2 activity by KEAP1 is essential for maintaining HSCs and guarantees their } \\
\text { stress-induced regenerative response. }\end{array}$ & 28674188,22039262 \\
\hline 70 & Oct-04 & $\begin{array}{l}\text { Oct- } 4 \text { is required for the initial specification of mesoderm and subsequently is required for the development } \\
\text { of hematopoietic cells from uncommitted mesoderm. }\end{array}$ & 19321862 \\
\hline 71 & Otx1 & $\begin{array}{l}\text { Plays a pivotal role in brain development and expressed in hematopoietic pluripotent and erythroid progenitor } \\
\text { cells. }\end{array}$ & 12934017,21050313 \\
\hline 72 & p400/mDomino & p400/mDomino plays a critical role in embryonic hematopoiesis. & 17535249 \\
\hline 73 & Pax5 and PU.1 & $\begin{array}{l}\text { EDAG was a transcriptional regulator which had transactivation activity and regulated the expression of } \\
\text { several key transcription factors such as PU. } 1 \text { and Pax5 in transgenic hematopoietic stem cells. }\end{array}$ & 17690693 \\
\hline 74 & PcG & $\begin{array}{l}\text { Polycomb group proteins are major negative regulators of gene expression in mammals and plays a role in } \\
\text { normal and malignant hematopoiesis. }\end{array}$ & 30341152 \\
\hline 75 & PEBP2/CBF & Plays an important role in angiogenesis. & 10644985 \\
\hline 76 & PITX2 & $\begin{array}{l}\text { Paired-like homeodomain transcription factor } 2 \text { (PITX2) gene plays a critical role in cell proliferation, } \\
\text { differentiation, hematopoiesis, and organogenesis. }\end{array}$ & $\begin{array}{l}24076438,24076438, \\
16195330\end{array}$ \\
\hline 77 & Prep1 & $\begin{array}{l}\text { Pre-B-cell leukemia homeobox (Pbx)-regulating protein-1 (Prep1) involved in early development, genomic } \\
\text { stability, insulin sensitivity, and hematopoiesis. }\end{array}$ & 25157139,25157139 \\
\hline 78 & PSC & Posterior Signaling Centre (PSC) is dispensable for blood cell progenitor maintenance. & 26150488 \\
\hline 79 & PU.1 & $\begin{array}{l}\text { Purine-rich box1 has a key role in the development of most hematopoietic cell lineages but also in the } \\
\text { suppression of leukemia. PU. } 1 \text { is developmentally upregulated during normal human myelopoiesis. }\end{array}$ & 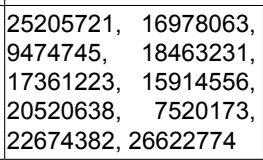 \\
\hline 80 & RARs and PLZF & Retinoic acid receptors (RARs) plays role in hematopoiesis. & 14521715 \\
\hline 81 & RUNX1/2/3 & $\begin{array}{l}\text { Runt-related transcription factor } 1 \text { hematopoietic master regulator plays role in hematopoiesis and represses } \\
\text { the erythroid gene expression program during megakaryocytic differentiation. Runx1, Runx2, or Runx3 } \\
\text { subunit, along with a non-DNA binding CBF } \beta \text { subunit required at one or more stages of hematopoiesis. }\end{array}$ & $\begin{array}{ll}25749719, & 23613270 \\
25847244, & 25911237 \\
27020276, & 26060100, \\
27137656, & 25263451 \\
11756550, & 20711992 \\
16890157, & 26060100 \\
16674921, & 28926098 \\
26590920, & 22024923 \\
24561082, & 25802202 \\
25847244, & 22411814 \\
28012022, & 15156179 \\
16390320 & \end{array}$ \\
\hline 82 & SALL4 & Role in developmental events as well as embryonic stem cell pluripotency maintenance. & 22555391,24163373 \\
\hline 83 & $\mathrm{SCL}$ & $\begin{array}{l}\text { Transcription factor stem cell leukemia (SCL), also known as the T-cell acute lymphocytic leukemia } 1 \\
\text { (TAL1), plays a key role in the regulation of hematopoiesis by modulating the phosphorylation level of the } \\
\text { key proteins in MEK/ERK pathway. }\end{array}$ & 24405580,23974202 \\
\hline 84 & SNAI2 and SNAI3 & $\begin{array}{l}\text { Snail family of transcription factors, both SNAI2 and SNAI3 deletion was required to fully impact the } \\
\text { generation of mature T and B cells. }\end{array}$ & 24674754 \\
\hline 85 & SOX11 & $\begin{array}{l}\text { SRY (sex determining region Y)-box } 11 \text { involved in tissue remodeling during embryogenesis and is crucial } \\
\text { for neurogenesis. }\end{array}$ & 21124928 \\
\hline 86 & Sox17 & $\begin{array}{l}\text { SOX17 plays a key role in priming hemogenic potential in endothelial cells, thereby regulating hematopoietic } \\
\text { development from hESCs/iPSCs. }\end{array}$ & 23169777 \\
\hline 87 & Sp3 & $\begin{array}{l}\text { Zinc-finger transcription factor specificity protein } 3(\mathrm{Sp} 3) \text { has been implicated in the regulation of many } \\
\text { hematopoietic-specific genes and showed their role in the erythroid and myeloid cell lineages. }\end{array}$ & 12676787 \\
\hline 88 & Spi-1 & Role in zebrafish myeloid cell differentiation & 19131555,24850855 \\
\hline 89 & $\begin{array}{l}\text { SPI1, GATA3, TCF-7, Etv5, } \\
\text { c-maf, and TBX21 }\end{array}$ & Differentially methylated in specific cell lineages and stages of the hematopoietic cascade. & 17433759 \\
\hline 90 & Srf & $\begin{array}{l}\text { Serum response factor (Srf) is a MADS-box transcription factor, critical for muscle differentiation. Srf is } \\
\text { required for normal megakaryocyte maturation and platelet production. }\end{array}$ & 20525922 \\
\hline 91 & STAT & $\begin{array}{l}\text { Signal transducer and activator of transcription proteins play a key role in the production of mature } \\
\text { hematopoietic cells. Signal transducer and activator of transcription } 3 \text { is a key transcriptional mediator for } \\
\text { many cytokines and is essential for normal embryonic development, development, and regulation of innate } \\
\text { immunity. Deletion of STAT3 during hematopoiesis results in abnormalities in myeloid cells and causes } \\
\text { Crohn's disease-like pathogenesis. STAT5 does not play a significant role in the regulation of proliferation of } \\
\text { normal hematopoietic cells derived from cord blood. STAT5 activated by SHP2 in GF-mediated proliferation, } \\
\text { survival, and differentiation of human progenitor cells. }\end{array}$ & $\begin{array}{ll}23797472, & 12571365 \\
18234692, & 29914167 \\
21085192, & 21670473 \\
11287618, & 23565285 \\
25550197, & 20508164 \\
17630355, & 12393407 \\
12813566 & \end{array}$ \\
\hline 92 & $\begin{array}{l}\text { STAT3, GATA1, and ZBP- } \\
89 \text { (ZNF148) }\end{array}$ & $\begin{array}{l}\text { PTPN9 plays an important role in erythropoiesis by disrupting an inhibitory complex of phosphorylated } \\
\text { STAT3, GATA1, and ZBP-89. }\end{array}$ & 24727614 \\
\hline
\end{tabular}


Citation: Raghav PK, Gangenahalli G (2018) Hematopoietic Stem Cell Molecular Targets and Factors Essential for Hematopoiesis. J Stem Cell Res Ther 8: 441. doi: 10.4172/2157-7633.1000441

Page 8 of 16

\begin{tabular}{|c|c|c|c|}
\hline 93 & STG I & $\begin{array}{l}\text { Shrimp crustin Pm4 and STG I as novel RNA binding proteins that play an important role in down-regulating } \\
\text { astakine expression at the post-transcriptional level and are crucial for the maintenance of hematopoiesis. }\end{array}$ & 24013515 \\
\hline 94 & SWI/SNF & $\begin{array}{l}\text { Genomic instability linked to helicase-like transcription factor deregulation, and strongly suggests a tumor } \\
\text { suppressor function of the SWI/SNF protein in acute myeloid leukemia. }\end{array}$ & 26802049 \\
\hline 95 & SZF1/ZNF589 & $\begin{array}{l}\text { Stem cell zinc finger } 1 \text { (SZF1)/ZNF589 epigenetically repress transcription by recruiting chromatin-modifying } \\
\text { complexes to the promoter regions of their respective target genes. }\end{array}$ & 26738774 \\
\hline 96 & TEAD & $\begin{array}{l}\text { The TEAD family transcription factor Scalloped regulates blood progenitor maintenance and proliferation in } \\
\text { Drosophila through PDGF/VEGFR receptor (Pvr) signaling. }\end{array}$ & 28322737 \\
\hline 97 & TEL & $\begin{array}{l}\text { TEL (translocation-ETS-leukemia or ETV6) locus, is frequently rearranged in human leukemias of myeloid or } \\
\text { lymphoid origin and required specifically for hematopoiesis within the bone marrow. }\end{array}$ & 9694803 \\
\hline 98 & Tfe3 & $\begin{array}{l}\text { Transcription Factor for Immunoglobulin Heavy-Chain Enhancer } 3 \text { (Tfe3), regulates the expression of MAFB } \\
\text { during macrophage differentiation. }\end{array}$ & 19332055 \\
\hline 99 & TIF1Y & $\begin{array}{l}\text { Plays essential roles in multiple murine blood lineages and that its function in transcription elongation is } \\
\text { evolutionally conserved. }\end{array}$ & 23159334 \\
\hline 100 & TRF3 & $\begin{array}{l}\text { TATA-box-binding protein (TBP)-related factor } 3 \text {, is required for early development and initiation of } \\
\text { hematopoiesis in zebrafish. }\end{array}$ & 19777587 \\
\hline 101 & VDR & $\begin{array}{l}\text { Vitamin } \mathrm{D} \text { receptor mediates the actions of its ligand, 1,25-dihydroxy vitamin } \mathrm{D}(3)[1,25(\mathrm{OH})(2) \mathrm{D}(3)] \text {, which } \\
\text { can promote monocyte/macrophage differentiation and inhibit proliferation and cytokine production by } \\
\text { activated T lymphocytes. }\end{array}$ & 11956247,28635660 \\
\hline 102 & WT1 & The Wilms tumor gene 1 (WT1) affects proliferation and differentiation in erythroid and myeloid cells. & 15907324,11237525 \\
\hline 103 & XBP-1 & Essential for hepatocyte growth. & 10652269 \\
\hline 104 & YBX1 & Y-box protein is involved in erythroid cell development & 21369783,21369783 \\
\hline 105 & ZBP-89 & $\begin{array}{l}\text { ZBP-89 (Zfp148) plays a critical role in erythroid lineage development, with its loss at the embryonic stage } \\
\text { causing lethal anemia and thrombocytopenia. Also, a direct repressor of PU.1 and activator of SCL/Tal1 and } \\
\text { GATA-1. }\end{array}$ & $\begin{array}{l}24549639, \quad 23936136, \\
25319994\end{array}$ \\
\hline 106 & ZFP191 & $\begin{array}{l}\text { ZFP191 played an essential role in aggressive proliferation and migration of VSMCs, which in turn facilitated } \\
\text { intimal hyperplasia. }\end{array}$ & 23755975 \\
\hline 107 & ZNF191 & $\begin{array}{l}\text { Human zinc finger protein } 191 \text { (ZNF191) interact with the widespread TCAT motif which constitutes the } \\
\text { HUMTH01 microsatellite in the tyrosine hydroxylase (TH) gene. }\end{array}$ & 18096443 \\
\hline 108 & ZNF24 & $\begin{array}{l}\text { Zinc finger transcription factor } 24 \text { is involved in negative regulation of vascular endothelial growth factor } \\
\text { (VEGF) and PDGFR- } \beta \text { and may represent a novel repressor of VEGF and PDGFR- } \beta \text { transcription respectively. } \\
\text { Implicated in transcriptional regulation of genes associated with hematopoiesis, brain development, and } \\
\text { cancers, oncogenesis. }\end{array}$ & 20510677,22678762 \\
\hline
\end{tabular}

Table 3: Role of a transcription factor in hematopoiesis.
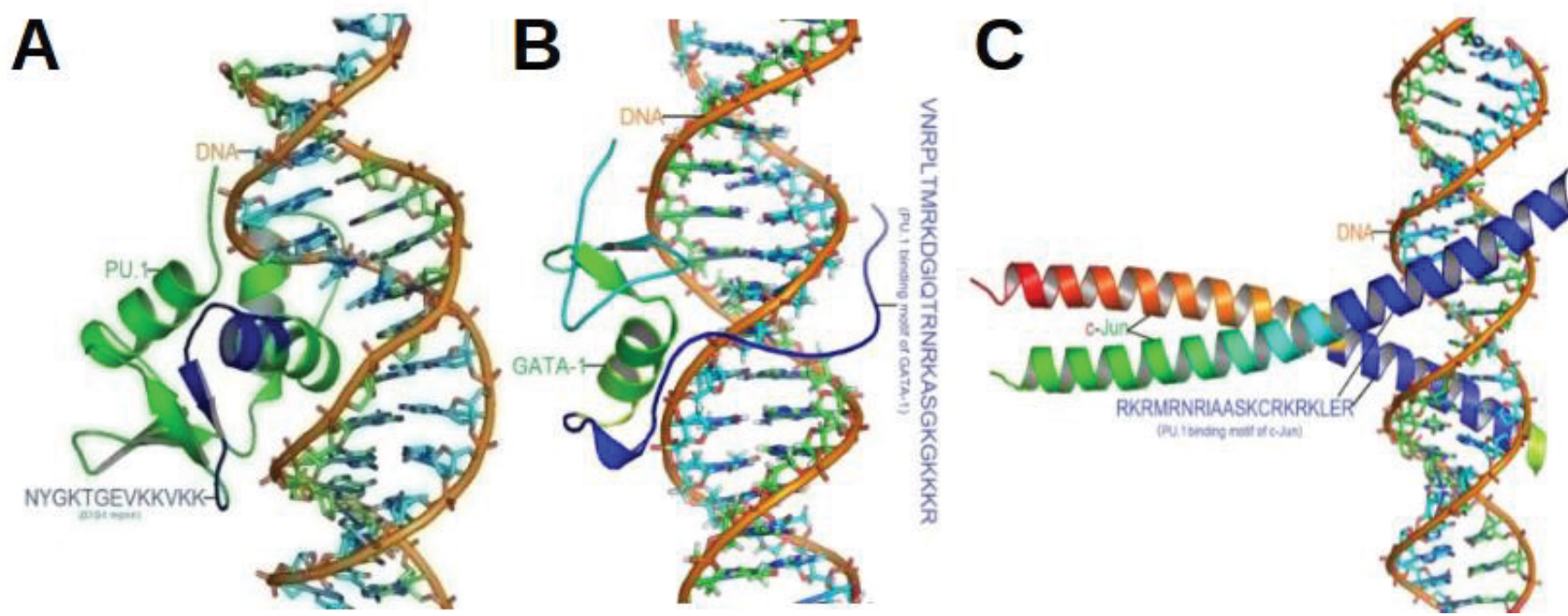

Figure 3: Transcription factors with DNA binding domain (A) binding site of PU.1 for GATA-1 and c-Jun (B) binding site of GATA-1 for PU.1, and (C) binding site of c-Jun for PU.1 shown as ligand pocket represented by binding sequence (blue color).

to SpiB (43\%) and SpiC (40\%) family. Spi subfamily of PU.1 belongs to the family of ETS associated factors underneath the class of tryptophan cluster, further classified under Helix turn helix domains superclass [48]. PU.1 protein is the target of phosphorylation events, noticeable on serine 148 [49]. PU.1 possesses three domains, an activation domain (10-13 amino acids), a PEST domain (118-170 amino acids), and an ETS DNA-binding domain (100 amino acids). In the PEST domain, residues 41 and 45 are essential for the enhancement of macrophage proliferation [50].

The PU.1, a master regulator of hematopoiesis, promotes lineagespecific differentiation of HSC in granulopoiesis and myelopoiesis [51,52]. In contrast, GATA-1 is involved in erythroid or megakaryocytic or eosinophil, and lymphopoiesis differentiation. The GATA-1 comes 
under the two-zinc finger GATA factors subfamily of GATA-type zinc fingers family which further comes under other $\mathrm{C} 4$ zinc finger-type factors class, originated from Zinc coordinating DNA binding domains superclass. Importantly, acetylation sites, lys312, lys314, and lys315 of GATA-1 were found blocked after binding with PU.1 [53]. Table 4 shows the intermolecular hydrogen bonding of PU.1 and GATA-1 complex $[53,54]$.

The PU.1, GATA-1, and GATA-2 are recognized as lineage-specific transcription factors that are expressed in MPP cells [55]. Yeast twohybrid screen, in vitro Glutathione S-Transferase (GST) pull-down, and in vivo immunoprecipitation assays reported that the DNA-binding domain of PU.1 interacts with the zinc finger region of GATA-2 similar to GATA-1 [56]. Nevertheless, dysregulation of either PU.1 or GATA1 activity leads to leukemogenesis [57-60]. However, manipulating the relative expression levels, by inhibiting GATA-1 or activating PU.1 or vice versa, led to differentiation of leukemic blasts cell differentiation into erythroleukemia [61,62]. Evaluation of the PU.1 and GATA-1 expressions is very important for the determination of MPP cell fate otherwise it can block cell differentiation and expansion of a clonal population of leukemic cells.

Besides, GATA-1 expresses in Megakaryocytic or Erythroid Progenitors (MEPs) that result in megakaryocyte and red blood cell precursors, whereas $\mathrm{C} / \mathrm{EBP} \alpha$ is present in GMPs [63]. However, according to Transfac database, c-Jun comes under the Jun factors subfamily of Jun related factors family under the bZIP class of Basic domain superclass (http://genexplain.com/transfac/). Likewise, C/ EBPa falls under the C/EBP related factors family, Basic Domains class and Leucine zipper factors (bZIP) superfamily [43].

Direct antagonism between C/EBP and FOG1, EKLF and Fli-1, GATA- 3 and T-bet, and Gfil and PU.1 shows a relationship among cell fate for eosinophil and multipotential, erythroid and megakaryocytic, TH1 and TH2, and neutrophil and monocyte cells, respectively. Nevertheless, without Gfil in mice, neutrophil precursors fail to mature and incompletely silence monocyte or macrophage gene expression [63]. Myeloid cells contained a high expression of PU.1 and C/EBP. These altogether with more widely expressed factors, AML1, ETS1, and c-Myb, activates myeloid specific promoters, such as the murine neutrophil elastase, G-CSF, M-CSF, and GM-CSF promoters [51]. The transcription regulators, Early growth response-1/2 (Egr-1/2) and NGFI-a binding protein 2 (Nab2), induces macrophage differentiation that needs a high-level of PU.1 expression [53].

Among these transcription factors, Mixed Lineage Leukemia (MLL), Runx1, TEL/ETV6, SCL/tal1, and LMO2 genes, contributes

\begin{tabular}{|c|c|c|c|}
\hline \multicolumn{2}{|c|}{ Reported PU.1 interacting residues } & \multicolumn{2}{c|}{ Reported GATA-1 interacting residues } \\
\hline In paper & In PDB (1PUE) & In paper & In PDB (1GAT) \\
\hline L172 & L174 & H289 & H38 \\
\hline Y173 & Y175 & R293 & R42 \\
\hline W213 & W215 & Q290 & Q39 \\
\hline N219 & N221 & L288 & L37 \\
\hline M228 & M230 & L284 & L33 \\
\hline K227 & K229 & G283 & G32 \\
\hline Y225 & Y227 & S310 & S59 \\
\hline E207 & E209 & & \\
\hline K245 & K247 & & \\
\hline H205 & H207 & & \\
\hline
\end{tabular}

Table 4: PU.1 interacting residue with GATA-1. to the most known leukemia-associated translocations in patients [64]. The transcription factor, SCL encourages myeloid differentiation, whereas, E2A (a helix-loop-helix protein) is needed for lymphoid development $[65,66]$. PU.1 with low expression level leads to lymphoid commitment whereas, a high expression expedites myeloid cells development [67]. Runx1 increases the PU.1 expression and contributes to cell commitment to the CMP lineage [68]. The basic-Helix-LoopHelix (bHLH), SCL/tal-1 and associated protein partner, and the Limdomain containing LMO2 are essential to developing both primitive and definitive (adult) hematopoietic systems. Similarly, in the absence of Runx1, no hematopoietic clusters are formed in the dorsal aorta in mice. In zebrafish, Runx1 lies downstream of Notch signaling, required to induce hematopoiesis [63].

\section{Role of proliferation in hematopoiesis}

HSCs play a crucial role in homeostasis, immune response, and in transplantation to treat numerous diseases [69]. The maintenance, self-renewal, and proliferation of HSCs are necessary for advanced HSC expansion. Hematopoiesis has an essential role in improving the efficiency of expansion for the transplantation [70]. Transplantation of stem cells into irradiated recipients, reconstitute hematopoiesis with resultant average life spans. Transplantation requires two essential properties, proliferation to renew the stem cell compartment (self-renewal) and lifelong production of blood cells [71]. These characteristics are regulated by ligands, macromolecules, and drugs (Table 5) [22,70,72-75].

\begin{tabular}{|c|c|c|c|}
\hline $\begin{array}{l}\text { S. } \\
\text { No. }\end{array}$ & $\begin{array}{l}\text { Molecules/ } \\
\text { genes/ } \\
\text { drugs }\end{array}$ & Function & PUBMED ID \\
\hline 1 & Wnt3A/5 & $\begin{array}{l}\text { Increases self-renewal 3- fold in culture. } \\
\text { Induce proliferation of B- cell precursors in a } \\
\text { LEF-1 dependent manner. Suppresses tissue } \\
\text { recovery. }\end{array}$ & $\begin{array}{l}27077077 \\
27698112 \\
18957545 \\
21693582 \\
19365403\end{array}$ \\
\hline 2 & Bmi-1 & $\begin{array}{l}\text { Deficiency results in decreased self-renewal } \\
\text { but overexpression increases self-renewal. } \\
\text { Represses the gene encoding cell cycle } \\
\text { regulator INK4A }\end{array}$ & $\begin{array}{l}16778178 \\
26028528\end{array}$ \\
\hline 3 & $\begin{array}{l}\text { Retinoic } \\
\text { acid }\end{array}$ & $\begin{array}{l}\text { Alterations in Hox gene expression and also } \\
\text { modifies Wnt-mediated signaling pathway. } \\
\text { Maintains HSCs in culture and can increase } \\
\text { self- renewal in serial transplantation } \\
\text { experiments. }\end{array}$ & 17846663 \\
\hline 4 & $\begin{array}{l}\text { DNMT3A } \\
\text { and } \\
\text { DNMT3B }\end{array}$ & Required for DNA methylation in HSCs & 17420264 \\
\hline 5 & p21 & $\begin{array}{l}\text { Lack results in higher rate of HSC } \\
\text { proliferation and differentiation, lower } \\
\text { self- renewal capacity. Hence required for } \\
\text { maintaining HSC quiescence }\end{array}$ & $\begin{array}{l}12795424 \\
22039255\end{array}$ \\
\hline 6 & Axin & $\begin{array}{l}\text { Abnormal/aberrant expression inhibits HSC } \\
\text { proliferation, increased cell death of HSCs in } \\
\text { vitro and reduced reconstitution in vivo }\end{array}$ & 11689955, \\
\hline 7 & $\begin{array}{l}\text { Valproic } \\
\text { acid }\end{array}$ & $\begin{array}{l}\text { Increases both proliferation and self- renewal, } \\
\text { accelerates cell cycle progression, down- } \\
\text { regulates p21cip1/waf1, inhibits GSK3 } \beta \\
\text { thereby activating Wnt signaling pathway, } \\
\text { up-regulates Hoxb4, induces differentiation } \\
\text { or apoptosis in leukemic blasts, increases the } \\
\text { replating capacity of murine HSC }\end{array}$ & 15805245 \\
\hline 8 & Laq824 & Properties similar to valproic acid on HSC & 15805245 \\
\hline 9 & $\begin{array}{l}\text { Stem } \\
\text { Regenin } \\
(\mathrm{SR}-1)\end{array}$ & $\begin{array}{l}\text { Increases ex vivo expansion of peripheral } \\
\text { blood-derived CD34+ cells by } 50 \text { fold }\end{array}$ & 26669897 \\
\hline
\end{tabular}

Table 5: Molecules, genes or drugs that regulate HSC proliferation and their selfrenewal characteristic. 
Binding of SCF to c-Kit causes receptor dimerization that maintains self-renewal and proliferation of HSCs. SCF acts synergistically with CSF such as GM-CSF, IL-3, and EPO, which in turn activates c-Kit intrinsic tyrosine kinase activity [76]. Dimerization occurs due to simultaneous binding of a dimeric SCF molecule with two c-Kit monomers [77,78]. Afterward, autophosphorylation of tyrosine residues of activated c-Kit occurs mainly outside the kinase domain. These residues serve as docking sites for STATs, signal transduction molecules containing SH2 or phosphotyrosine (pY) binding domains, Shc, Grb2, IRS1/2 and PI3K molecules [79]. The critical residues that undergo autophosphorylation, which is in the Juxtamembrane (JM) domain, include Y568 and Y570. The primary function of $\mathrm{c}$-Kit is the progression of proliferation in HSCs, regulated by the PI3K and the MAPK pathway. The c-Kit has the potential to be involved in multiple signal transduction pathways via interaction with several enzymes and adaptor proteins (Figure 4) [80]. The adaptor proteins, APS, Src Family Kinases (SFK), and SHP-2, binds with phosphorylated Y568 (pY568) whereas, SHP-1 and adaptor protein Shc binds with phosphorylated Y570 (pY570). However, C-terminal Src homologous kinase (Chk) and the adaptor Shc binds in the JM domain at pY568 and pY570 of c-Kit. Also, Growth factor receptor-bound protein-2 (Grb2), PI3K, and phospholipase $\mathrm{C}$ bind at pY703, pY721, and pY730 respectively, in the Kinase Insert Domain (KID) of c-Kit. The pY900 in Distal Kinase Domain (DKD) binds to PI3K which further activates the adaptor protein Crk. The pY936 in the DKD binds with the adaptor proteins APS, Grb2, and Grb7 [80]. These c-Kit interactions result in the activation of several signal transduction pathways as shown in Figure 4. Besides, phosphorylated STATs, generated as homodimers and heterodimers of STAT, later translocate to the nucleus to influence transcription that leads to proliferation, survival, and differentiation [27-29].

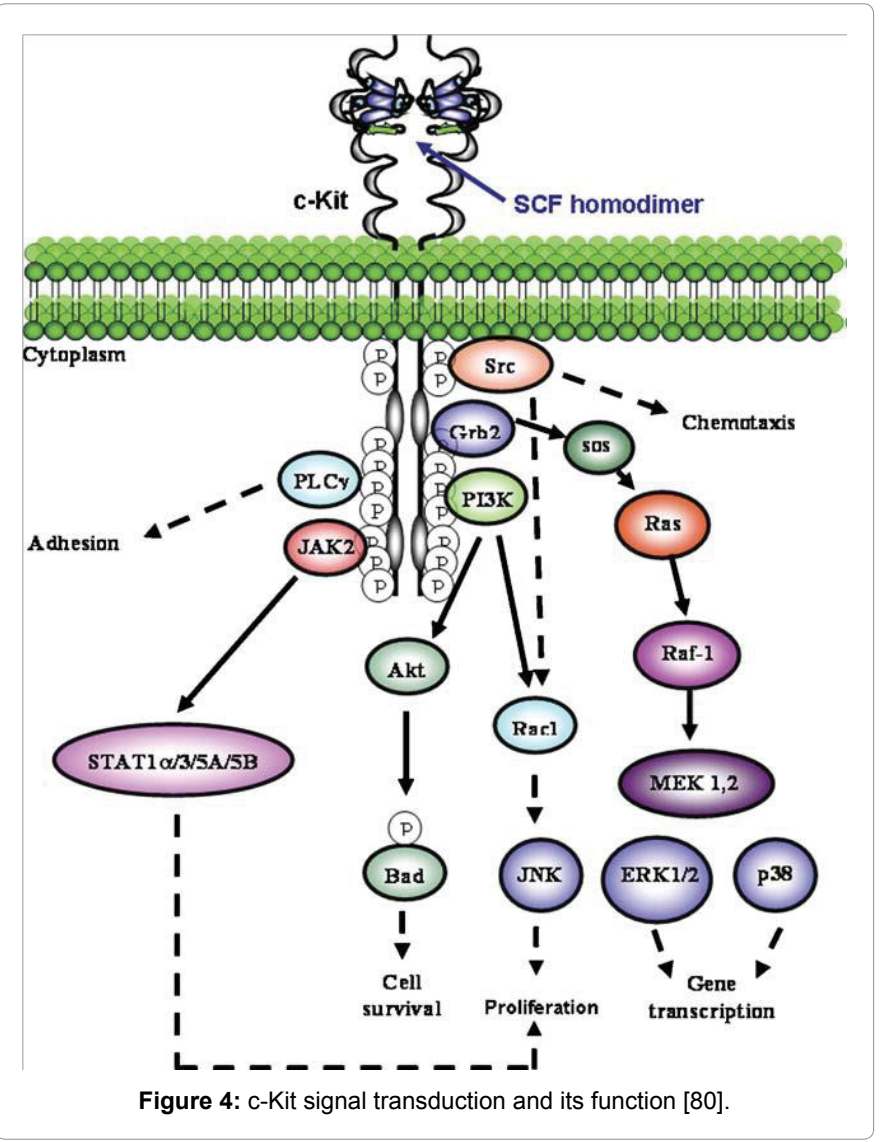

Grb2 is an adaptor protein that plays a critical role in MAPK pathway by binding to pY703 and pY936 of c-Kit [81]. The complex of Grb2 with son-of-sevenless (sos) protein interacts with G-protein Ras and initiates activation of Raf- 1 and finally the MAPK p38, ERK1/2, and c-Jun N-terminal Kinase (JNK). This evident that MAPK acts on transcription factors activity, and thereby on gene transcription. Reportedly, the Ras/Erk pathway is crucial in cell division and survival [82]. Even though Ras can activate some signal transduction molecules such as Rac or PI3K, its role in the Ras/Erk cascade is the most well characterized $[83,84]$.

PI3K Pathway promotes proliferation by PI3K interaction with pY721 of c-Kit [85]. SCF-induced PI3K recruitment leads to Akt activation that subsequently phosphorylates the pro-apoptotic protein, bad. This indispensable mechanism of phosphorylation inhibits the activity of Bad, thereby promoting cell survival [86]. PI3K is also known to mediate SCF-induced proliferation of Bone Marrow-derived Mast Cells (BMMC) by activating the small Guanosine Triphosphate (GTP) binding protein Rac1 and JNK pathways $[87,88]$.

Phospholipase C- $\gamma$ (PLC- $\gamma$ ) association site phosphorylated at Y730 of c-Kit [89]. PLC- $\gamma$ exists in two isoforms, PLC- $\gamma 1$ and PLC- $\gamma 2$, wherein both are composed of two SH2 domains, one $\mathrm{SH} 3$ domain, one $\mathrm{PH}$ domain, and a catalytic domain. Although PLC- $\gamma 1$ is ubiquitously expressed, PLC- $\gamma 2$ is mainly indicated in the hematopoietic system [90]. PLC hydrolyzes the phosphoinositide PIP2, thereby generating the second messengers DAG and inositol-1,4,5-trisphosphate (IP3).

The SCF triggers the multiple SFK members including Src, Tec, Lyn, and Fyn for their association with pY568 and pY570 in the JM domain of c-Kit [91-95]. After SCF stimulation in BMMC, Src kinase, and PI3K signaling pathways converge to turn on Racl and JNK, promoting cell proliferation [88]. However, inhibition of SCF-induced proliferation reduces the expression of the Lyn [92]. Gene transcription, induced by SCF, is also facilitated by activation of members of the SFK, leading to activation of the Ras/MAPK pathway $[81,96]$.

In the JAK/STAT pathway, the Janus Kinases (JAKs) are cytoplasmic tyrosine kinases activated through ligand stimulation of cytokine receptors. Downstream of JAKs are the Signal Transducers and Activators of Transcription (STATs), which are phosphorylated by JAKs. STAT protein is a class of transcription factors with DNA binding domains, an $\mathrm{SH} 2$ domain, and a carboxy-terminal transactivating domain. SCF induces activation of the JAK/STAT pathways. JAK2 associates with c-Kit and later undergoes phosphorylation after SCF stimulation [97]. The activation of JAK2 leads to phosphorylation of STAT1a, 3, 5A and 5B [98]. SCF-induced JAK/STAT activation is involved in fetal liver hematopoietic progenitor cell proliferation and differentiation [99]. However, SCF $(100 \mathrm{ng} / \mathrm{ml})$ activates JAK/STAT pathway in MO7e and HCD57 cells [100].

\section{Pathways regulating hematopoiesis}

LT-HSCs are identifying in human bone marrow CD34+ CD38CD90+ isolated cells which can repopulate a lethally irradiated animal and establish a life-long supply of all hematopoietic lineages. Also, CD34+ or CD34lo cells have higher repopulating potential characterized by side population analysis by flow cytometry [101]. CD34+ cells promote adhesion with decreased proliferation due to their cell cycle expression kept in the niche [102]. Further, ST-HSCs result in all hematopoietic lineages, but only 8-10 weeks. Assume that ST-HSCs is an intermediate cell stage between LT-HSCs and the more lineagerestricted progenitors as they are the Common Myeloid Progenitor (CMP) and the Common Lymphoid Progenitor (CLP) population. In 
a further set of decisions, CLPs translated into the different cells of the lymphatic lineage like B-lymphocytes, T-lymphocytes and NK cells. In contrast, CMP differentiates into cells of the myeloid lineage like granulocytes, macrophages, erythrocytes, and thrombocytes. Besides, numerous pathways with their role in regulating hematopoiesis are enumerated in Table 6 (searched from PUBMED).

Majorly, hematopoiesis pathway involves lymphoid (T-cells, B-cells, natural killer cells, and Dendritic Cells (DC)); myeloid (Red Blood Cells (RBCs)), granulocytes (neutrophils, eosinophils, basophils)); mast cells; monocyte-macrophages; and megakaryocytes-platelets; and an additional mechanism for generating DC. The HSC differentiation of mature hematopoietic cells, cell surface markers, transcription factors, and the growth factors that impact the differentiation is represented in Figure 2.

The CD34+ CD38+ CD45RA+ CD10+ from in vitro culture of bone marrow CLPs characterized the B-cell, NK, and DC progenitors [103]. Also, injected CD34+ CD10+ cells into fetal thymic organs successfully promoted into T-cells [103]. The PU.1 promotes IL-7Ra (a diagnostic marker for murine and human marrow CLPs) and EBF1 expression, while Ikaros promotes Flt3 receptor expression, important for B-cell and T-cell development [104]. Deleting or inhibiting the Notch receptor signaling promotes B-cells progress and inhibits T-cell formation [105]. B-cells was characterized by a CD19+ marker but derived from CD34+ CD19- CD10+ cells. The c-Kit and FLT3 activate the B-cell proliferation and survival, whereas, cytokine IL-7 promotes CD19 expression [106]. The transcription factors, FoxP1, E2A/E47, and EBF, regulates the B-cell development. However, interacting chemokine receptor and ligand (CCR9 and CCL25, respectively) endorse immature T-cell progenitors to migrate towards the thymus [107]. These developing cells characterized by CD34+ CD1a- as Early Thymic Progenitors (ETP), however, CD1a+ CD4- CD8- recognized as pro-T-cells. The SCF, Flt3, and BMP promoted T-cell development and required for maintenance of the undifferentiated lymphoid precursors [108,109]. A bipotent T/NK Progenitor (TKNP) found in the human fetal thymus was characterized using $\mathrm{CD} 34+\mathrm{CD} 7+\mathrm{CD} 1 \mathrm{a}$, which found as the immediate precursor of NK Progenitors (NKP) and T-cells in the thymus [109].
CMPs also knew as CFU-GEMM results in all types of the myeloid lineage. CMPs differentiates into intermediate MPP, such as Granulocyte-Monocyte Progenitors (GMP), which produces neutrophils, eosinophils, basophils, and monocyte or macrophages, and Megakaryocyte-Erythroid Progenitors (MEP) that produces erythroid and megakaryocytes. The CMP, GMP, and MEP are deficient in lymphoid markers, CD10, CD7, and IL-7Ra, but characterized by CD34+ CD38+ markers from human marrow and cord blood which have CD45RA and IL-3Ra expression. Although, CD45RA- IL-3Ralo characterized the CMPs whereas, CD45RA+ IL-3Ralo and CD45RAIL-3Ra- markers characterized the GMPs, and MEPs, respectively. The myeloid marker, CD33 is highly expressed on CMPs but lost beyond the myelocyte stage. Therefore, it is a known target for treating certain types of Acute Myeloid Leukemia (AML) [110]. In contrast, Flt3 expression found positive in around $40-80 \%$ of human CD34+ bone marrow and cord blood cells and contributed for long-term repopulation. Colony forming assay revealed that higher GM colonies identified in Flt3+ population and Flt3- shows more erythroid colonies [111]. PU.1 and GATA-1 control lineage bifurcation between the MEP and GMP populations, respectively. PU.1 promotes GMP formation whereas, GATA-1 influences MEP development.

In colony forming assay, MEP differentiates into Burst Forming Unit-Megakaryocytic (BFU-Mk) or Burst Forming Unit-Erythroid (BFU-E), and later into Colony Forming Units-Megakaryocytic (Mk$\mathrm{CFU}$ ) or Colony Forming Units-Erythroid (E-CFU), respectively. These colonies are further mature terminally into megakaryocyte or platelet or erythroid cells. MEP cells controlled by transcription factors (SCL, GATA-1, GATA-2, and NF-E2), cell surface molecules (TER119, CD235a/glycophorin A), and cytokines (IL-3, SCF, EPO, and TPO). Similarly, EPO and TPO play an indispensable role in MEP downstream signaling by binding to their respective cell surface receptors to stimulate the growth of MEP progenitors. The restricted transcription factors, Fli-1 and EKLF, decide the fate of MEPs towards BFU-Mk and BFU-E formation, respectively. Interestingly, GATA-1 and CP1 promote to express EKLF. Alternatively, megakaryocytic lineage express CD41, CD61, CD42, glycoprotein V, von Willebrand factor, platelet factor 4 and platelet proteins. In contrast, lost expression of CD41 after MEP progress

\begin{tabular}{|c|c|c|c|}
\hline S. No. & Pathways & Role & PMID \\
\hline 1 & Cell death pathway & $\begin{array}{l}\text { RIPK1 is a critical modulator of both tonic and TLR-responsive inflammatory and cell death pathways in } \\
\text { human macrophage differentiation. }\end{array}$ & 30250197 \\
\hline 2 & HSCs Survival pathways & $\begin{array}{l}\text { cpsf1 inactivation implicates this gene in the maintenance and survival of key cell lineages, including normal } \\
\text { HSCs and a subset of the diverse neural crest-derived lineages in zebrafish. }\end{array}$ & 21330472 \\
\hline 3 & Innate immune pathway & $\begin{array}{l}\text { The prominent role of the innate immune pathway in regulating hematopoiesis. Increased activation of the } \\
\text { innate immune pathway may contribute to dysregulated hematopoiesis, dysplasia, and clonal expansion in } \\
\text { myelodysplastic syndromes. }\end{array}$ & 20359630 \\
\hline 4 & $\begin{array}{l}\text { Jak/STAT, PI3K/AKT, and } \\
\text { MAPK pathways }\end{array}$ & $\begin{array}{l}\text { Binding of IL-31 to its receptor activates Jak/STAT, PI3K/AKT, and MAPK pathways. IL-31 acts on a broad } \\
\text { range of immune- and non-immune cells and therefore possesses potential pleiotropic physiological } \\
\text { functions, including regulating hematopoiesis and immune response, causing inflammatory bowel disease, } \\
\text { airway hypersensitivity, and dermatitis. }\end{array}$ & 18926762 \\
\hline 5 & Leptin-signaling pathways & $\begin{array}{l}\text { Role of leptin in immunity and leptin-signaling pathways involved in modulating immune homeostasis and } \\
\text { autoimmune pathogenesis. leptin in regulating hematopoiesis and lymphopoiesis }\end{array}$ & 17349207 \\
\hline 6 & Megakaryopoiesis & $\begin{array}{l}\text { ATP-binding cassette }(\mathrm{ABC}) \text { transporters regulate megakaryopoiesis and platelet activity, the underlining } \\
\text { mechanisms and their association with atherosclerosis and atherothrombosis. }\end{array}$ & 28641133 \\
\hline 7 & inositide & $\begin{array}{l}\text { phosphoinositide-phospholipase PI-PLCY1 is essential for regulating hematopoiesis, particularly along } \\
\text { myeloid and erythroid lineage. }\end{array}$ & 25307310 \\
\hline 8 & $\begin{array}{l}\text { Shh and Wnt Signaling } \\
\text { Pathways }\end{array}$ & Regulating the proliferation of hematopoietic progenitor cells (HPCs). & 26378473 \\
\hline 9 & $\begin{array}{l}\text { Wnt and Notch signaling } \\
\text { pathways }\end{array}$ & $\begin{array}{l}\text { Wht and Notch signalings are integrated and are selectively regulating hematopoiesis. Upregulates } \\
\text { proliferation potential of hematopoietic progenitors }\end{array}$ & 20217087 \\
\hline 10 & Wnt/B-catenin network & $\begin{array}{l}\text { Wnt/ } \beta \text {-catenin signaling pathway has been shown to play an important role in controlling the proliferation, } \\
\text { survival, and differentiation of hematopoietic cells. Thus any aberrant signaling through this pathway may } \\
\text { have a negative influence on hematopoiesis. }\end{array}$ & 18726147 \\
\hline
\end{tabular}

Table 6: Pathways regulating hematopoiesis. 
but a continued expression of CD71 at the BFU-E stage reported. These premature erythrocytes later promote erythroid membrane proteins, erythroid enzymes, and hemoglobin. Megakaryocytes pathway involves the generation of promegakaryoblasts that leads to megakaryoblasts and in turn forms megakaryocytes. Megakaryocyte or platelet produces from the CFU-Mk stage wherein, cell division fails to replicate DNA but leads to produce larger cells containing $4 \mathrm{~N}$ to $128 \mathrm{~N}$ in nuclei. Proplatelets produced by cytoplasmic fragmentation of megakaryocytes, afterward, 2,000-3,000 platelets made from single megakaryocyte cells [112]. Among multiple cytokines (SCF, GM-CSF, IL-3, IL-6, IL-7, IL-11, and TPO), the TPO and IL-3 are required for platelets generation [113]. GATA-1 and GATA-2 expression promote erythroid and megakaryocytic lineage differentiation, respectively but GATA-2 instead contributes to the proliferation of progenitor cells [114]. The SCF, GM-CSF, IL-3, and TPO arose before the CFU-E stage afterward, EPO helps to prevent apoptosis, induce hemoglobin synthesis and generate pro-erythroblasts. Consequently, EPO is not required at this stage which proceeds through nucleated normoblast to enucleated RBCs [115]. Cells with low expression of proliferative genes (GATA2, c-Myb, c-Myc, and c-Kit) and high expression of differentiationpromoting genes (glycophorin A, and B globins) improve lineage commitment to erythroid cells [116-118].

GMP differentiated into neutrophils, eosinophils, and basophils passing through intermediate stages of myeloblast, promyelocyte, myelocyte, metamyelocyte, and mature granulocyte. Neutrophils and monocytes identified using CD11B, CD13, CD14, CD15, and CD16 markers. Nevertheless, G-CSF, GM-CSF, and IL-3 are critically stimulating the generation of granulocytes. The C/EBPa is interacting with c-Jun which increases the activity of PU.1, whereas inhibiting Pax5 (paired box gene 5), and other lymphoid transcriptional elements, leads to GMP lineage commitment. This association of c-Jun raised PU.1 expression, which controls granulocytic with low, and monocytic with high lineage commitment. The lineage commitment pathway by PU.1 contains the antagonistic role of Egr1/2-Nat2, which drives macrophage gene expression and inhibits neutrophil gene expression. On the contrary, Gfi- 1 is the downstream target of $\mathrm{C} / \mathrm{EBPa}$, which represses the interaction of Egr-1/2 and Nab-2 [119,120]. Furthermore, GMP differentiates into eosinophil-basophil progenitors that generate eosinophils under the influence of cytokines IL-3, IL-5, and GM-CSF and transcriptional regulators like GATA-1, PU.1, and C/EBP [121]. Interestingly, IL-5 is specific for eosinophils, and their overproduction leads to death, eosinophilia [122]. Nonetheless, GATA-1 has an essential role in eosinophil generation, while this finding ineffective in megakaryocytes, erythroid and mast cell lineage development [122]. However, basophils drew from a bipotent precursor with both eosinophil and basophil differentiation capacity [123]. The expression of CD34, c-Kit, and CD13 characterized the mast cell and basophil progenitors $[124,125]$. Cord blood progenitors cultured with IL-3 differentiates basophil $[126,127]$. The IL-3, TGF- $\beta$, and IL-18, synergistically inhibits eosinophil differentiation and increase IL-4/histamine production in basophils. Similarly, GM-CSF and IL-5 promote basophil production [123]. In contrast, SCF and IL-3 besides TPO, leukotriene D4, T helper type II (Th2), IL-4, IL-5, IL-6, and IL-9 are vital for mast cell development [128-131]. Additionally, SCF alone activates proliferation and degranulation in human mast cells [132]. GATA-2, associated with proliferation does not antagonize PU.1, results in increased PU.1 expression which promotes mast cell differentiation [43]. Besides, GMP differentiates into another lineage called as Macrophage Dendritic Progenitor (MDP) which gives both monocytes, macrophages, and lymphoid or non-lymphoid and plasmacytic dendritic cells. CD115,
M-CSFR receptor expression recognizes the monocyte development from MDP [133]. Human monocytes expressing CD64+ CD14+ CD16-, hold higher CCR2 (chemokine) receptor and low CX3CR1 expression. They have high phagocytic/myeloperoxidase activity, superoxide release, and monocyte also secretes IL-10 on stimulating with Lipopolysaccharide (LPS). In contrast, lower CD16+ monocytes expression shows the opposite effect. PU.1 antagonizes GATA-1, GATA-2 and C/EBPa, which in turn inhibits MEP, mast cell, and granulocytic formation respectively to commit cells into the monocytic lineage $[43,134]$.

DC-derived from both myeloid and lymphoid progenitors, classified into proliferative Early DC Progenitors (EDCP), Late DC Progenitors (LDCP) with limited proliferative capacity, and non-proliferative Gr1hi monocytic and DC precursors potential. EDCP are lineage-negative cells characterized by c-Kit, while LDCP is negative c-Kit, but express CD11. Further, mature DCs classed into "migratory" DCs (mDCs) (non-lymphoid) and lymphoid tissue-resident, "plasmacytic" DCs (pDCs,) produces interferons, and "conventional" DCs (cDCs) (opposes mDCs with pDCs). During inflammation, the GM-CSF, and TNF- $\alpha$ differentiate monocyte to $\mathrm{CDC}$, whereas M-CSF and TGF- $\beta 1$ facilitate Langerhans Cell (LC) development although TPO show synergism with Flt3L and G-CSF while, alone increases pDC development and mobilization [135]. Flt3L activates STAT3 which decreases DC numbers whereas, Gfi-1 activates them which reduces lymphoid-derived DCs while increasing LC production [136,137]. M-CSF activates STAT5 that promotes $\mathrm{CDC}$ development which suppresses IRF-8 (ICSBP) and supports the inhibition of pDC development. Overwhelmingly, GMCSF generates pDCs without STAT5, which increases STAT3 activation and IRF-4 expression [138]. Interestingly, STAT3 signaling increased PU.1 expression and formed both cDC and pDC [139].

\section{Conclusion}

Stem cells are identified as pluripotent and multipotent cells found in bone marrow which can differentiate into any tissue in the body. Though pluripotent ESCs are more efficient than multipotent adult stem cells in producing any cell type, many ethical issues have been raised towards the use of ES cells [69]. Therefore, current investigative approaches are looking at using pluripotent stem cells in replacement therapies as they regenerate functional tissues for multiple injuries, spinal cord injury, and can cure Alzheimer's and diabetes. Pluripotent stem cells possess their characteristic properties, self-renewal, and differentiation, regulated by factors like mitogens, cytokines, small molecules, nutrients, cell-cell contacts and extracellular matrix [140]. Thus, designing a drug for stem cells requires a deep understanding of its elemental properties and factors which regulate these properties. Besides, Infectious diseases (typhoid, hepatitis, tuberculosis, diphtheria, whooping cough, polio, and pneumonia) caused by fecal matter contaminated water, and poor living conditions would likely be solved by inducing stem cells to differentiates selectively into myeloid cells. The myelopoiesis is accomplished by precise regulation of interaction of GATA-1 (42.7 kDa) and c-Jun (41.9 kDa) with PU.1, a transcription factor that controls erythroid and myeloid development, respectively [5]. Nevertheless, sequence comparison of c-Jun and GATA-1 motifs reveals the extensive similarity between the two proteins. This analogy agrees with the observation that GATA-1 and c-Jun compete for the same binding site on PU.1. Therefore, the elucidation of the molecular mechanism underlying this interaction is required which is not yet known. Furthermore, it has been noted that a large number of stem cells $\left(2 \times 10^{6} \mathrm{CD} 34+\right.$ cells $/ \mathrm{kg}$ recipient body weight $)$ is needed for a successful BMT [71]. Thus, the study of proliferation is inevitable 
Citation: Raghav PK, Gangenahalli G (2018) Hematopoietic Stem Cell Molecular Targets and Factors Essential for Hematopoiesis. J Stem Cell Res Ther 8: 441. doi: 10.4172/2157-7633.1000441

Page 13 of 16

to identify a capable molecule that transiently expands stem cells. Moreover, SCF regulates the downstream kinase signaling by interacting with c-Kit, which is prominently present on HSCs to derive proliferation [80]. The SCF binding to c-Kit monomer extracellular region triggers dimerization and induces autophosphorylation of c-Kit in the intracellular region. These phosphorylated residues are docking sites for SFK, Cbl, SHP-2, Lnk, and APS binds at Y568; SHP1 at Y570; Grb2 at Y703; p85 and p110 (subunit of PI3K or CrkL) at Y721; phospholipase C at Y730; p85 associated with Crk at Y900; and Grb2, Grb7 and APS at Y936 [80]. These interactions suggest that these targets can modulate well established signaling routes like PI3K, Src family kinases, MAPK pathways and phospholipases that further regulate proliferation and mitogenic index of hematopoietic cells. This phenomenon revealed that proliferation would likely be improved by the synergistic effect of drugs and cytokines. Additionally, it can also be enhanced by abrogating the negative regulator of $\mathrm{c}$-Kit which would lead to their autophosphorylation of tyrosine residues and inhibition of dephosphorylation. This binding would likely play an essential role in regulating tyrosine phosphorylation and cell proliferation.

\section{Acknowledgment}

All authors acknowledge Defence Research and Development Organisation (DRDO) for providing financial help. Authors also thankful of Mrs. Rajni (CARA Delhi, India) for proofread of review.

\section{Author Contributions}

P.K.R. and G.U.G. conceived the idea and designed the outline of the review. P.K.R wrote the review with input and critical guidance from G.U.G

\section{Conflict of Interest}

All authors declare that they do not have conflicts of interest.

\section{References}

1. Kirouac DC, Zandstra PW (2008) The systematic production of cells for cell therapies. Cell Stem Cell 3: 369-381. [PubMed]

2. Mahdavi A, Davey RE, Bhola P, Yin T, Zandstra PW (2007) Sensitivity analysis of intracellular signaling pathway kinetics predicts targets for stem cell fate control. PLoS Comput Biol 3: 1257-1267. [PubMed]

3. Malgieri A, Kantzari E, Patrizi MP, Gambardella S (2010) Bone marrow and umbilical cord blood human mesenchymal stem cells: State of the art. Int J Clin Exp Med 3: 248-269. [PubMed]

4. Gupta P, Gurudutta GU, Saluja D, Tripathi RP (2009) PU.1 and partners: Regulation of hematopoietic stem cell fate in normal and malignant haematopoiesis. J Cell Mol Med 13: 4349-4363. [PubMed]

5. Gangenahalli GU, Gupta P, Saluja D, Verma YK, Kishore V, et al. (2005) Stem cell fate specification: role of master regulatory switch transcription factor PU.1 in differential hematopoiesis. Stem Cells Dev 14: 140-152. [PubMed]

6. Rizo A, Vellenga E, de Haan G, Schuringa JJ (2006) Signaling pathways in self-renewing hematopoietic and leukemic stem cells: Do all stem cells need a niche? Hum Mol Genet 15: 210-219. [PubMed]

7. Lander AD, Kimble J, Clevers H, Fuchs E, Montarras D, et al. (2012) What does the concept of the stem cell niche really mean today? BMC Biol 10: 19. [PubMed]

8. Muench MO, Firpo MT, Moore MAS (1993) Bone marrow transplantation with interleukin-1 plus kit-ligand ex vivo expanded bone marrow accelerates hematopoietic reconsiitution in mice without the loss of stem cell lineage and proliferative potential. Blood 81: 3463-347.

9. Begley CG, Metcalf D, Nicola NA (1987) Purified colony stimulating factors (G CSF and GM-CSF) induce differentiation in human HL60 leukemic cells with suppression of clonogenicity. Int J Cancer 39: 99-105. [PubMed]

10. Czechowicz A, Kraft D, Weissman IL, Bhattacharya D (2007) Efficien transplantation via antibody-based clearance of hematopoietic stem cell niches. Science 318: 1296-1299. [PubMed]

11. Dorsch M, Fan PD, Danial NN, Rothman PB, Goff SP (1997) The thrombopoietin receptor can mediate proliferation without activation of the Jak-STAT pathway. $J$ Exp Med 186: 1947-1955. [PubMed]

12. Sharma S, Gurudutta GU, Satija NK, Pati S, Afrin F, et al. (2006) Stem cell c-KIT and HOXB4 genes: critical roles and mechanisms in self-renewal, proliferation, and differentiation. Stem Cells Dev 15: 755-778. [PubMed]

13. Raghav PK, Singh AK (2018) Stem cell factor and NSC87877 synergism enhances c-Kit mediated proliferation of human erythroid cells. Life Sci 214 84-97. [PubMed]

14. Haylock DN, To LB, Dowse TL, Juttner CA, Simmons PJ (1992) Ex vivo expansion and maturation of peripheral blood CD34+ cells into the myeloid lineage. Blood 80: 1405-1412. [PubMed]

15. Blank U, Karlsson S (2015) TGF- $\beta$ signaling in the control of hematopoietic stem cells. Blood 125: 3542-3550 [PubMed]

16. Birbrair A, Frenette PS (2016) Niche heterogeneity in the bone marrow. Ann N Y Acad Sci 1370:82-96. [PubMed]

17. Domen J, Wagers A, Weissman IL (2006) Bone marrow (Hematopoietic) stem cells. Regen Med Washington, DC Dep. Heal Hum Serv, pp: 13-34.

18. Metcalf D (2007) Concise review: hematopoietic stem cells and tissue stem cells: current concepts and unanswered questions. Stem Cells 25: 2390-2395. [PubMed]

19. Morrison SJ, Weissman IL (1994) The long-term repopulating subset of hematopoietic stem cells is deterministic and isolatable by phenotype. Immunity 1: 661-673. [PubMed]

20. Wagers AJ, Christensen JL, Weissman IL (2002) Cell fate determination from stem cells. Gene Ther 9: 606-612. [PubMed]

21. Weissman IL (2000) Stem cells: units of development, units of regeneration and units in evolution. Cell 100: 157-168. [PubMed]

22. Zon LI (2008) Intrinsic and extrinsic control of haematopoietic stem-cell selfrenewal. Nature 453: 306-313. [PubMed]

23. Placzek MR, Chung IM, Macedo HM, Ismail S, Mortera Blanco T, et al. (2009) Stem cell bioprocessing: fundamentals and principles. J R Soc Interface 6: 209232. [PubMed]

24. Metcalf D (1988) Haemopoietic growth factors. Med J Aust 333: 825-827.

25. Shah BD, Zuckerman KS (2011) Normal and malignant hematopoiesis. In Advances in Malignant Hematology, pp: 1-30.

26. McCubrey JA, Steelman LS, Abrams SL, Bertrand FE, Ludwig DE, et al. (2008) Targeting survival cascades induced by activation of Ras/Raf/MEK/ERK, PI3K PTEN/Akt/mTOR and Jak/STAT pathways for effective leukemia therapy. Leukemia 22: 708-722. [PubMed]

27. Platanias LC (2003) Map kinase signaling pathways and hematologic malignancies. Blood 101: 4667-4679. [PubMed]

28. Vivanco I, Sawyers C (2002) The phosphatidylinositol 3-Kinase-AKT pathway in human cancer. Nat Rev Cancer 2: 489-501. [PubMed]

29. Ward AC, Touw I, Yoshimura A (2000) The Jak-Stat pathway in normal and perturbed hematopoiesis. Blood 95: 19-29. [PubMed]

30. Li MO, Wan YY, Sanjabi S, Robertson AKL, Flavell R (2006) Transforming growth factor-beta regulation of immune responses. Annu Rev Immunol 24 99-146. [PubMed]

31. Dolence JJ, Gwin KA, Shapiro MB, Medina KL (2014) Flt3 signaling regulates the proliferation, survival, and maintenance of multipotent hematopoietic progenitors that generate B cell precursors. Exp Hematol 42: 380-393. [PubMed]

32. Josefsen D, Myklebust JH, Lomo J, Sioud M, Blomhoff HK, et al. (2000) Differential expression of bcl-2 homologs in human CD34(+) hematopoietic progenitor cells induced to differentiate into erythroid or granulocytic cells. Stem Cells 18: 261-272. [PubMed]

33. Iwasaki H, Akashi K (2007) Hematopoietic developmental pathways: on cellular basis. Oncogene 26: 6687-6696. [PubMed]

34. Aggarwal R, Lu J, Pompili VJ, Das H (2012) Hematopoietic stem cells: transcriptional regulation, ex vivo expansion and clinical application. Curr Mo Med 12: 34-49. [PubMed]

35. Stopka T, Amanatullah DF, Papetti M, Skoultchi Al (2005) PU.1 inhibits the 
Citation: Raghav PK, Gangenahalli G (2018) Hematopoietic Stem Cell Molecular Targets and Factors Essential for Hematopoiesis. J Stem Cell Res Ther 8: 441. doi: 10.4172/2157-7633.1000441

Page 14 of 16

erythroid program by binding to GATA-1 on DNA and creating a repressive chromatin structure. EMBO J 24: 3712-3723. [PubMed]

36. Zhang P, Behre G, Pan J, Iwama A, Wara-Aswapati N, et al. (1999) Negative cross-talk between hematopoietic regulators: GATA proteins repress PU.1. Proc Natl Acad Sci USA 96: 8705-8710. [PubMed]

37. Hohaus S, Petrovick MS, Voso MT, Sun Z, Zhang DE, et al. (1995) PU.1 (Spi-1) and $\mathrm{C} / \mathrm{EBP}$ alpha regulate expression of the granulocyte-macrophage colonystimulating factor receptor alpha gene. Mol Cell Biol 15: 5830-5845. [PubMed]

38. Hong W, Kim AY, Ky S, Rakowski C, Seo SB, et al. (2002) Inhibition of CBPmediated protein acetylation by the Ets family oncoprotein PU.1. Mol Cell Biol 22: 3729-3743. [PubMed]

39. Nagulapalli S, Pongubala JM, Atchison ML (1995) Multiple proteins physically interact with PU.1. Transcriptional synergy with NF-IL6 beta (C/EBP delta, CRP3). J Immunol 155: 4330-4338. [PubMed]

40. Oelgeschläger M, Nuchprayoon I, Lüscher B, Friedman D (1996) C/EBP, $\mathrm{c}-\mathrm{Myb}$, and PU.1 cooperate to regulate the neutrophil elastase promoter. Mol Cell Biol 16: 4717-4725. [PubMed]

41. Perkel JM, Atchison ML (1998) A two-step mechanism for recruitment of Pip by PU.1. J Immunol 160: 241-252. [PubMed]

42. Petrovick MS, Hiebert SW, Friedman D, Hetherington CJ, Tenen DG, et al (1998) Multiple functional domains of AML1: PU.1 and C/EBPalpha synergize with different regions of AML1. Mol Cell Biol 18: 3915-3925. [PubMed]

43. Reddy VA, Iwama A, lotzova G, Schulz M, Elsasser A, et al. (2002) Granulocyte inducer C/EBPa inactivates the myeloid master regulator PU.1: Possible role in lineage commitment decisions. Blood 100: 483-490. [PubMed]

44. Rehli M, Poltorak A, Schwarzfischer L, Krause SW, Andreesen R, et al. (2000) PU.1 and interferon consensus sequence-binding protein regulate the myeloid expression of the human toll-like receptor 4 gene. J Biol Chem 275: 9773-9781. [PubMed]

45. Rekhtman N, Radparvar F, Evans T, Skoultchi Al (1999) Direct interaction of hematopoietic transcription factors PU.1 and GATA-1: Functional antagonism in erythroid cells. Genes Dev 13: 1398-1411. [PubMed]

46. Vangala RK, Heiss-Neumann MS, Rangatia JS, Singh SM, Schoch C, et al. (2003) The myeloid master regulator transcription factor PU.1 is inactivated by AML1-ETO in t(8;21) myeloid leukemia. Blood 101: 270-277. [PubMed]

47. Walsh JC, DeKoter RP, Lee HJ, Smith ED, Lancki DW, et al. (2002) Cooperative and antagonistic interplay between PU.1 and GATA-2 in the specification of myeloid cell fates. Immunity 17: 665-676. [PubMed]

48. Fisher RC, Scott EW (1998) Role of PU.1 in hematopoiesis. Stem Cells 16 25-37. [PubMed]

49. Brass AL, Kehrli E, Eisenbeis CF, Storb U, Singh H (1996) Pip, a lymphoidrestricted IRF, contains a regulatory domain that is important for autoinhibition and ternary complex formation with the Ets factor PU.1. Genes Dev 10: 23352347. [PubMed]

50. Celada A, Borràs FE, Soler C, Lloberas J, Klemsz M, et al. (1996) The transcription factor PU.1 is involved in macrophage proliferation. J Exp Med 184: 61-69. [PubMed]

51. Hoppe PS, Schwarzfischer M, Loeffler D, Kokkaliaris KD, Hilsenbeck O, et al (2016) Early myeloid lineage choice is not initiated by random PU.1 to GATA1 protein ratios. Nature 535: 299-302.

52. Kastner P, Chan S (2008) PU.1: A crucial and versatile player in hematopoiesis and leukemia. Int J Biochem Cell Biol 40: 22-27 [PubMed]

53. Chu WL, Rand KD, Simpson RJY, Yung WW, Mansfield RE, et al. (2006) Molecular analysis of the interaction between the hematopoietic master transcription factors GATA-1 and PU. J Biol Chem 281: 28296-28306. [PubMed]

54. Nouri M, Deezagi A, Ebrahimi M (2016) Reprogramming of human peripheral blood monocytes to erythroid lineage by blocking of the PU-1 gene expression. Ann Hematol 95: 549-556. [PubMed]

55. Gao J, Chen YH, Peterson LC (2015) GATA family transcriptional factors: emerging suspects in hematologic disorders. Exp Hematol Oncol 4: 28 [PubMed]

56. Lee ME, Temizer DH, Clifford JA, Quertermous T (1991) Cloning of the GATA- binding protein that regulates endothelin-1 gene expression in endothelial cells. J Biol Chem 266: 16188-16192. [PubMed]

57. Li Z, Godinho FJ, Klusmann JH, Garriga-Canut M, Yu C, et al. (2005) Developmental stage-selective effect of somatically mutated leukemogenic transcription factor GATA1. Nat Genet 37: 613-619. [PubMed]

58. Rosenbauer F, Wagner K, Kutok JL, Iwasaki H, Le Beau MM, et al. (2004) Acute myeloid leukemia induced by graded reduction of a lineage-specific transcription factor, PU.1. Nat Genet 36: 624-630. [PubMed]

59. Shimizu R, Kobayashi E, Engel JD, Yamamoto M (2009) Induction of hyperproliferative fetal megakaryopoiesis by an N-terminally truncated GATA1 mutant. Genes to Cells 14: 1119-1131. [PubMed]

60. Wechsler J, Greene M, McDevitt MA, Anastasi J, Karp JE, et al. (2002) Acquired mutations in GATA1 in the megakaryoblastic leukemia of Down syndrome. Nat Genet 32: 148-152. [PubMed]

61. Burda P, Vargova J, Curik N, Salek C, Papadopoulos GL, et al. (2016) GATA-1 inhibits PU.1 gene via DNA and histone H3K9 methylation of its distal enhance in erythroleukemia. PLoS One 11: e0152234. [PubMed]

62. Papetti M, Skoultchi Al (2007) Reprogramming leukemia cells to termina differentiation and growth arrest by RNA interference of PU.1. Mol Cancer Res 5: 1053-1062. [PubMed]

63. Orkin SH, Zon LI (2008) Hematopoiesis: an evolving paradigm for stem cell biology. Cell 132: 631-644. [PubMed]

64. Aplan PD (2006) Causes of oncogenic chromosomal translocation. Trends Genet 22: 46-55. [PubMed]

65. Hoang T (2004) The origin of hematopoietic cell type diversity. Oncogene 23 7188-7198. [PubMed]

66. Kunisato A, Chiba S, Saito T, Kumano K, Nakagami-Yamaguchi E, et al. (2004) Stem cell leukemia protein directs hematopoietic stem cell fate. Blood 103 3336-3341. [PubMed]

67. Laslo P, Spooner CJ, Warmflash A, Lancki DW, Lee HJ, et al. (2006) Multilineage transcriptional priming and determination of alternate hematopoietic cell fates. Cell 126: 755-766. [PubMed]

68. Huang G, Zhang P, Hirai H, Elf S, Yan X, et al. (2008) PU.1 is a major downstream target of AML1 (RUNX1) in adult mouse hematopoiesis. Na Genet 40: 51-60. [PubMed]

69. Bongso A, Lee EH (2005) Stem cells: their definition, classification and sources. Stem Cells-From Bench to Bedside Chapter 1: 1-13.

70. Chotinantakul K, Leeanansaksiri W (2012) Hematopoietic stem cell development, niches, and signaling pathways. Bone Marrow Res 2012: 1-16. [PubMed]

71. Burt RK, Loh Y, Pearce W, Beohar N, Barr WG, et al. (2008) Clinical applications of blood-derived and marrow-derived stem cells for nonmalignant diseases. JAMA 299: 925-936. [PubMed]

72. Bug G, Gül H, Schwarz K, Pfeifer H, Kampfmann M, et al (2005) Valproic acid stimulates proliferation and self-renewal of hematopoietic stem cells. Cancer Res 65: 2537-2541. [PubMed]

73. Kaur K, Mirlashari MR, Kvalheim G, Kjeldsen-Kragh J (2013) 3' 4'-Dimethoxyflavone and valproic acid promotes the proliferation of human hematopoietic stem cells. Stem Cell Res Ther 4: 60. [PubMed]

74. Roeven MWH, Thordardottir S, Kohela A, Maas F, Preijers F, et al. (2015) The aryl hydrocarbon receptor antagonist StemRegenin 1 improves in vitro generation of highly functional NK cells from CD34(+) hematopoietic stem and progenitor cells. Stem Cells Dev 24: 2886-2898. [PubMed]

75. Thordardottir S, Hangalapura BN, Hutten T, Cossu M, Spanholtz J, et al (2014) The aryl hydrocarbon receptor antagonist StemRegenin 1 promotes human plasmacytoid and myeloid dendritic cell development from CD34+ hematopoietic progenitor cells. Stem Cells Dev 23: 955-967. [PubMed]

76. Blume-Jensen P, Claesson-Welsh L, Siegbahn A, Zsebo KM, Westermark B, et al. (1991) Activation of the human c-kit product by ligand-induced dimerization mediates circular actin reorganization and chemotaxis. EMBO J 10: 4121 4128. [PubMed]

77. Lemmon MA, Pinchasi D, Zhou M, Lax I, Schlessinger J (1997) Kit recepto dimerization is driven by bivalent binding of stem cell factor. J Biol Chem 272 6311-6317. [PubMed] 
Citation: Raghav PK, Gangenahalli G (2018) Hematopoietic Stem Cell Molecular Targets and Factors Essential for Hematopoiesis. J Stem Cell Res Ther 8: 441. doi: 10.4172/2157-7633.1000441

78. Philo JS, Wen J, Wypych J, Schwartz MG, Mendiaz EA, et al. (1996) Human stem cell factor dimer forms a complex with two molecules of the extracellular domain of its receptor, Kit. J Biol Chem 271: 6895-6902. [PubMed]

79. Pawson T (2004) Specificity in signal transduction: from phosphotyrosine-SH2 domain interactions to complex cellular systems. Cell 116: 191-203. [PubMed]

80. Ronnstrand L (2004) Signal transduction via the stem cell factor receptor/c-Kit. Cell Mol Life Sci 61: 2535-2548. [PubMed]

81. Thommes K, Lennartsson J, Carlberg M, Ronnstrand L (1999) Identification of Tyr-703 and Tyr-936 as the primary association sites for Grb2 and Grb7 in the c-Kit/stem cell factor receptor. Biochem J 341: 211 [PubMed]

82. Lewis TS, Shapiro PS, Ahn NG (1998) Signal Transduction through MAP Kinase Cascades. Adv Cancer Res 74: 49-139. [PubMed]

83. Qiu RG, Chen J, Kirn D, McCormick F, Symons M (1995) An essential role for Rac in Ras transformation. Nature 374: 457-459. [PubMed]

84. Rodriguez-Viciana P, Warne PH, Khwaja A, Marte BM, Pappin D, et al. (1997) Role of phosphoinositide 3-OH kinase in cell transformation and control of the actin cytoskeleton by Ras. Cell 89: 457-467. [PubMed]

85. Serve H, Hsu YC, Besmer P (1994) Tyrosine residue 719 of the c-kit receptor is essential for binding of the P85 subunit of phosphatidylinositol (PI) 3-kinase and for c-kit-associated PI 3-kinase activity in COS-1 cells. J Biol Chem 269 : 6026-6030. [PubMed]

86. Blume-Jensen P, Janknecht R, Hunter T (1998) The kit receptor promotes cell survival via activation of $\mathrm{PI}$ 3-kinase and subsequent Akt-mediated phosphorylation of Bad on Ser136. Curr Biol 8: 779-782. [PubMed]

87. Fukao T, Yamada T, Tanabe M, Terauchi Y, Ota T, et al. (2002) Selective loss of gastrointestinal mast cells and impaired immunity in PI3K-deficient mice. Na Immunol 3: 295-304. [PubMed]

88. Timokhina I, Kissel H, Stella G, Besmer P (1998) Kit signaling through PI 3-kinase and Src kinase pathways: An essential role for Rac1 and JNK activation in mast cell proliferation. EMBO J 17: 6250-6262. [PubMed]

89. Gommerman JL, Sittaro D, Klebasz NZ, Williams DA, Berger SA (2000) Differential stimulation of c-Kit mutants by membrane-bound and soluble Steel Factor correlates with leukemic potential. Blood 96: 3734-3742. [PubMed]

90. Carpenter G, Ji Q (1999) Phospholipase C-y as a signal-transducing element. Exp Cell Res 253: 15-24. [PubMed]

91. Blume-Jensen P, Rönnstrand L, Gout I, Waterfield MD, Heldin CH (1994) Modulation of Kit/stem cell factor receptor-induced signaling by protein kinase C. J Biol Chem 269: 21793-21802. [PubMed]

92. Linnekin D, Deberry CS, Mou S (1997) Lyn associates with the juxtamembrane region of c-Kit and is activated by stem cell factor in hematopoietic cell lines and normal progenitor cells. J Biol Chem 272: 27450-27455. [PubMed]

93. Price DJ, Rivnay B, Fu Y, Jiang S, Avraham S, et al. (1997) Direct association of Csk homologous kinase (CHK) with the diphosphorylated site $\operatorname{Tyr}(568 / 570)$ of the activated c-KIT in megakaryocytes. J Biol Chem 272: 5915-5920. [PubMed]

94. Tang B, Mano H, Yi T, Ihle JN (1994) Tec kinase associates with c-kit and is tyrosine phosphorylated and activated following stem cell factor binding. Mol Cell Biol 14: 8432-8437. [PubMed]

95. Ueda S, Mizuki M, Ikeda H, Tsujimura T, Matsumura I, et al. (2002) Critical roles of c-Kit tyrosine residues 567 and 719 in stem cell factor-induced chemotaxis: Contribution of src family kinase and PI3-kinase on calcium mobilization and cell migration. Blood 99: 3342-3349. [PubMed]

96. Bondzi C, Litz J, Dent P, Krystal GW (2000) Src family kinase activity is required for Kit-mediated mitogen-activated protein (MAP) kinase activation, however loss of functional retinoblastoma protein makes MAP kinase activation unnecessary for growth of small cell lung cancer cells. Cell Growth Differ 11: 305-314. [PubMed]

97. Brizzi MF, Zini MG, Aronica MG, Blechman JM, Yarden Y, et al. (1994) Convergence of signaling by interleukin-3, granulocyte-macrophage colonystimulating factor, and mast cell growth factor on JAK2 tyrosine kinase. J Biol Chem 269: 31680-31684. [PubMed]

98. Brizzi MF, Dentelli P, Rosso A, Yarden Y, Pegoraro L (1999) STAT protein recruitment and activation in c-Kit deletion mutants. J Biol Chem 274: 1696516972. [PubMed]

99. Radosevic N, Winterstein D, Keller JR, Neubauer H, Pfeffer K, et al. (2004)
JAK2 contributes to the intrinsic capacity of primary hematopoietic cells to respond to stem cell factor. Exp Hematol 32: 149-156. [PubMed]

100. Gotoh A, Takahira H, Mantel C, Litz-Jackson S, Boswell HS, et al. (1996) Steel factor induces serine phosphorylation of Stat3 in human growth factordependent myeloid cell lines. Blood 88: 138-145. [PubMed]

101. Goodell MA, Rosenzweig M, Kim H, Marks DF, DeMaria M, et al. (1997) Dye efflux studies suggest that hematopoietic stem cells expressing low or undetectable levels of CD34 antigen exist in multiple species. Nat Med 3 : 1337-1345. [PubMed]

102. Gangenahalli GU, Singh VK, Verma YK, Gupta P, Sharma RK, et al. (2006) Hematopoietic stem cell antigen CD34: role in adhesion or homing. Stem Cells Dev 15: 305-313. [PubMed]

103. Galy A, Travis M, Cen D, Chen B (1995) Human T, B, natural killer, and dendritic cells arise from a common bone marrow progenitor cell subset. Immunity 3: 459-473. [PubMed]

104. Blom B, Spits H (2006) Development of human lymphoid cells. Annu Rev Immunol 24: 287-320. [PubMed]

105. Radtke F, Wilson A, Stark G, Bauer M, Van Meerwijk J, et al. (1999) Deficient T cell fate specification in mice with an induced inactivation of Notch1. Immunity 10: 547-558. [PubMed]

106. Goetz C, Harmon I, O’Neil J, Burchill M, Johanns T, et al. (2005) Restricted STAT5 activation dictates appropriate thymic $B$ versus $T$ cell lineage commitment. J Immunol 174: 7753-7763. [PubMed]

107. Wurbel MA, Philippe JM, Nguyen C, Victorero G, Freeman T, et al. (2000) The chemokine TECK is expressed by thymic and intestinal epithelial cells and attracts double-and single-positive thymocytes expressing the TECK receptor CCR9. Eur J Immunol 30: 262-271. [PubMed]

108. Rodewald HR, Kretzschmar K, Swat W, Takeda S (1995) Intrathymically expressed c-kit ligand (stem cell factor) is a major factor driving expansion of very immature thymocytes in vivo. Immunity 3: 313-319. [PubMed]

109. Wang H, Pierce LJ, Spangrude GJ (2006) Distinct roles of IL-7 and stem cell factor in the OP9-DL1 T-cell differentiation culture system. Exp Hematol 34 1730-1740. [PubMed]

110. Manz MG, Miyamoto T, Akashi, K, Weissman IL (2002) Prospective isolation of human clonogenic common myeloid progenitors. Proc Natl Acad Sci USA 99: 11872-11877. [PubMed]

111. Rappold I, Ziegler BL, Kohler I, Marchetto S, Rosnet O, et al. (1997) Functiona and phenotypic characterization of cord blood and bone marrow subsets expressing FLT3 (CD135) receptor tyrosine kinase. Blood 90: 111-125. [PubMed]

112. Battinelli EM, Hartwig JH, Italiano JE (2007) Delivering new insight into the biology of megakaryopoiesis and thrombopoiesis. Curr Opin Hematol 14: 419 426. [PubMed]

113. Kaushansky K (2008) Historical review: Megakaryopoiesis and thrombopoiesis Blood 111: 981-986 [PubMed]

114. Castor A, Nilsson L, Astrand-Grundström I, Buitenhuis M, Ramirez C, et al. (2005) Distinct patterns of hematopoietic stem cell involvement in acute lymphoblastic leukemia. Nat Med 11: 630-637. [PubMed]

115. Wu H, Liu X, Jaenisch R, Lodish HF (1995) Generation of committed erythroid BFU-E and CFU-E progenitors does not require erythropoietin or the erythropoietin receptor. Cell 83: 59-67. [PubMed]

116. Elmaagacli $A H$, Koldehoff $M$, Zakrzewski JL, Steckel NK, Ottinger $H$, et al. (2007) Growth factor-independent 1B gene (GFI1B) is overexpressed in erythropoietic and megakaryocytic malignancies and increases their proliferation rate. $\mathrm{Br} \mathrm{J}$ Haematol 136: 212-219. [PubMed]

117. Kuo YY, Chang ZF (2007) GATA-1 and Gfi-1B interplay to regulate Bcl-xL transcription. Mol Cell Biol 27: 4261-4272. [PubMed]

118. Loose M, Swiers G, Patient R (2007) Transcriptional networks regulating hematopoietic cell fate decisions. Curr Opin Hematol 14: 307-314. [PubMed]

119. Osawa M, Yamaguchi T, Nakamura Y, Kaneko S, Onodera M, et al. (2002) Erythroid expansion mediated by the Gfi-1B zinc finger protein: Role in norma hematopoiesis. Blood 100: 2769-2777. [PubMed]

120. Friedman AD (2007) Transcriptional control of granulocyte and monocyte development. Oncogene 26: 6816-6828. [PubMed] 
Citation: Raghav PK, Gangenahalli G (2018) Hematopoietic Stem Cell Molecular Targets and Factors Essential for Hematopoiesis. J Stem Cell Res Ther 8: 441. doi: 10.4172/2157-7633.1000441

Page 16 of 16

121. Boyce JA, Friend D, Matsumoto R, Austen KF, Owen WF (1995) Differentiation in vitro of hybrid eosinophil/basophil granulocytes: autocrine function of an eosinophil developmental intermediate. J Exp Med 182: 49-57. [PubMed]

122. Rothenberg ME, Hogan SP (2006) The eosinophil. Annu Rev Immunol 24 147-174. [PubMed]

123. Arock M, Schneider E, Boissan M, Tricottet V, Dy M (2002) Differentiation of human basophils: an overview of recent advances and pending questions. J Leukoc Biol 71: 557-564. [PubMed]

124. Horny HP, Parwaresch MR, Lennert K (1985) Bone marrow findings in systemic mastocytosis. Hum Pathol 16: 808-814. [PubMed]

125. Lawrence JB, Friedman BS, Travis WD, Chinchilli VM, Metcalfe DD, et al. (1991) Hematologic manifestations of systemic mast cell disease: a prospective study of laboratory and morphologic features and their relation to prognosis. Am J Med 91: 612-624. [PubMed]

126. Kepley CL, Pfeiffer JR, Schwartz LB, Wilson BS, Oliver JM (1998) The identification and characterization of umbilical cord blood-derived human basophils. J Leukoc Biol 64: 474-483. [PubMed]

127. Lindemann A, Ganser A, Herrmann F, Frisch J, Seipelt G, et al. (1991) Biologic effects of recombinant human interleukin-3 in vivo. J Clin Oncol 9: 2120-2127. [PubMed]

128. Jiang Y, Kanaoka Y, Feng C, Nocka K, Rao S, et al. (2006) Cutting edge: Interleukin 4-dependent mast cell proliferation requires autocrine/intracrine cysteinyl leukotriene-induced signaling. J Immunol 177: 2755-2759. [PubMed]

129. Kirshenbaum AS, Akin C, Goff JP, Metcalfe DD (2005) Thrombopoietin alone or in the presence of stem cell factor supports the growth of KIT (CD117) low/ MPL(CD110)+ human mast cells from hematopoietic progenitor cells. Exp Hematol 33: 413-421. [PubMed]

130. Kirshenbaum AS, Goff JP, Semere T, Foster B, Scott LM, et al. (1999) Demonstration that human mast cells arise from a progenitor cell population that is CD34(+), c-kit(+), and expresses aminopeptidase N (CD13). Blood 94 2333-2342. [PubMed]

131. Morita H, Saito H, Matsumoto K, Nakae S (2016) Regulatory roles of mas cells in immune responses. Semin Immunopathol 38: 623-629. [PubMed]

132. Söderholm JD (2010) Mast cells and mastocytosis. Dig Dis 1: 129-136 [PubMed]

133. Auffray C, Fogg DK, Narni-Mancinelli E, Senechal B, Trouillet C, et al. (2009) CX3CR1+ CD115+ CD135+ common macrophage/DC precursors and the role of CX3CR1 in their response to inflammation. J Exp Med 206: 595-606. [PubMed]

134.Dahl R, Walsh JC, Lancki D, Laslo P, lyer SR, et al. (2003) Regulation of macrophage and neutrophil cell fates by the PU.1:C/EBPa ratio and granulocyte colony-stimulating factor. Nat Immunol 4: 1029-1036. [PubMed]

135. Merad M, Manz MG (2009) Dendritic cell homeostasis. Blood 113: 3418-3427. [PubMed]

136. Laouar Y, Welte T, Fu XY, Flavell RA (2003) STAT3 is required for Flt3Ldependent dendritic cell differentiation. Immunity 19: 903-912. [PubMed]

137. Rathinam C, Geffers R, Yücel R, Buer J, Welte K, et al. (2005) The transcriptional repressor Gfi1 controls STAT3-dependent dendritic cell development and function. Immunity 22: 717-728. [PubMed]

138. Esashi E, Wang YH, Perng O, Qin XF, Liu YJ, et al. (2008) The signa transducer STAT5 inhibits plasmacytoid dendritic cell development by suppressing transcription factor IRF8. Immunity 28: 509-520. [PubMed]

139. Onai N, Obata-Onai A, Tussiwand R, Lanzavecchia A, Manz MG (2006) Activation of the Flt3 signal transduction cascade rescues and enhances type I interferon-producing and dendritic cell development. J Exp Med 203: 227238. [PubMed]

140. Reya T, Morrison SJ, Clarke MF, Weissman IL (2001) Stem cells, cancer, and cancer stem cells. Nature 414: 105-111. [PubMed] 